\title{
THE RISE AND FALL OF BUCKEYE 2: BUCKEYE, 1931-1959: MARITAL IMMUNITY FOR TORTS IN CONFLICT OF LAWS
}

\author{
Morfatt Hhicocxt
}

No at is more diffeult than the an of good gcrerrment and at the foundation of permanert good government mast be laid the uncroidably difficult and intricate seience of the low. If thase who realize this are to lead, it is necessors that they clear their minds of befogging spperstitions, mystifying dogmes, and the treadmills of inadequate generalitics and sophistical reasonins.

Josepg W. BIYGHAM!

\section{The Probley: Divergent Rules of Martial ManNTYY IN WISCONST AND ILUNOIS}

I N 1959, the Supreme Court of Wisconsin overruled its much discussed and often cited precedent, Buckeye r. Buckeye, ${ }^{2}$ which, ever since it was decided in 1931, had been regarded as one of the leading cases in the field. The Buckeye case involved a suit against the driver of a car brought by a bdy passenger for personal injuries sustained while they had been driving in Illinois. After the commencement of the action the plaintiff married the defendant They were both domiciled in Wisconsin. Under Illinois law (so it was thought) the marriage would have had the effect of extinguishing the canse of action; Wisconsin law, on the other hand, permitted wives to sue their husbands for personal torts committed before and after marriage. The Wisconsin court held that the Mlinois rule should control and dismissed the complaint. Although criticized by commentators, ${ }^{3}$ the decision was followed in five other states. 4 As late as 1955, the Supreme Court of Connecticut added

† Professor of Law, Sianford Lniversity. B.A., 1933, University of Toronto; LL.B., 1936, Ospoode Hall Law School; S.J.D., 1940, University of Michigan.

1 Bingham, What is the Lax? 11 Micr. L. Rrv. 109, 119 (1912).

2203 Wis. 248, 234 N.W. 342 (1931), overruled in Haumschild v. Continental Cas. Co., 7 Wis. $2 d$ 130, 95 N.W.2d 814 (1959).

3 See text at note 71 infra.

II the same year that the Buckeye case was decided two other state courts, without jiting it, reached the same result in closefy similar cases. Dawson v. Dawion, $224 \mathrm{Ala}$.13, 138 So. 414 (1931); Howard v. Honard, 200 X.C. 574, 158 S.E. 101 (1931). The Buckeye ase was cited and followed in Bohenek v. Niedzwiecki, 142 Conn. 278, 113 A.2d 509 (1955); Gray v. Gray, 87 Y.H. 82, 174 Atl. 508 (1934); Coster v. Coster, 289 X.Y. 438, 46 N.E.2d 509 (1943). 
that state to the list.5 Thus, after a notable career of judicial approval both at home and abroad, extending over a quarter of a century, this landmark case in the conflict of laws was discredited and repudiated in the very court where it had been decided. How could such a strange event come to pass?

Considering this question in a general fashion, we tend to resist the notion that Buckeye v. Buckeye was the product of some hasty and ill-considered first step in the trial and error process of courthouse government, for this would not explain the deliberate congruent holdings in other states. We may suspect, however, that the concurrent criticisms of the commentators had some effect and we may even indulge an optimistic fancy that the Haumschild case, ${ }^{6}$ overruling Buckeye v. Buckeye, represents the emergence of a new judicial approach to choice-of-law problems. But these are mere hypotheses. To test them we must examine the discredited precedent more carefully to see what interests were at stake and the manner in which these interests were disposed. Modern exegesis suggests that in analyzing a choice-of-law problem one should begin by considering not merely the bare bones of the domestic rules of law but the underlying conflict of policies which each domestic rule of law has attempted to resolve. ${ }^{7}$ Let us turn, then, to the Illinois law of husband and wife as it appeared to be in 1931 .

According to contemporary writers, 8 the leading Illinois case in 1931 was Main v. Main, ${ }^{9}$ decided by an appellate court in 1892 . After divorce, a woman had sued her former husband for false imprisonment in causing her to be confined to an insane asylum during coverture. Deciding for the defendant on a demurrer to his plea of coverture, the court pointed out that at common law neither spouse could sue the other for a personal tort. While local statutes had been held to permit married women to litigate property matters with their husbands, "sound considerations of public policy would forbid a change of the common law and unless the statutory provisions referred to have by direct terms or necessary inference abrogated the rule we must hold it still in force. It is clear that this has not been done, expressly, and we find no sufficient warrant for saying it has been done by implication."10 Strangely, the court did not see fit to quote or discuss further the "statutory provisions re-

5 Bohenek v. Niedzwiecki, supra note 4. This case was followed in Bissonette v. Bissonette, 145 Conn. 733, 142 A.2d 527 (1958).

6 Haumschild v. Continental Cas. Co., 7 Wis. 2d 130, 95 N.W.2d 814 (1959).

7 Currie, Married Women's Contracts: A Study in Conflict of Laws Method, 25 U. CHI. L. REv. 227 (1958); Currie \& Lieberman, Purchase-Money Mortgages and State Lines: A Study in Conflict of Laws Method, 1960 Duke L.J. 1; Freund, Chief Justice Stone and the Conflict of Laws, 59 HARv. L. REv. 1210 (1946); Traynor, Is This Conflict Really Necessary? 37 TEXAs L. REV. 657 (1959); Yntema, The Objectives of Private International Law, 35 CAN. B. REv. 721, 730-40 (1957).

8 See Note, 22 ILL. B.J. 19 (1933); Note, 19 ILL. L. REV. 199 (1924).

946 IIl. App. 106 (1892).

1046 IIl. App. at 108. 
ferred to,"11 but they were of a type which has been regarded as particularly unfavorable to the contention that suit against the husband for personal torts has been authorized.12 Since the clause enabling a married woman to sue and be sued as if she were unmarried contained the words "without joining her husband," it appeared to do no more than change the procedural rule requiring a husband to join in litigation between his wife and third parties.

To support the policy of the common law rule, the court urged that the divorce decree ought to settle all causes of complaint between the parties. Otherwise, "a new line of litigation would arise and the harvest would grow in proportion to the number of divorces." 13 Some courts of that era were reaching similar results by asserting the desirability of preventing domestic discord and preserving the harmony of the home. ${ }^{14}$ Although this ground was not urged by the court in the Main case, a consideration of the contention is relevant to an analysis of our problem.

11 The court ought to have been referring to ILL. REv. STAT. ch. $68, \S 1$ (1874): "That a married woman may, in all cases, sue and be sued without joining her husband with her, to the same extent as if she were unmarried, and an attachment or judgment in such action may be enforced by or against her as if she were a single woman." In Welch v. Davis, 342 III. App. 69, 75 (1950) it was said that Main v. Main was not an authoritative precedent on the effect of the act of 1874 because that act had not been specifically cited and Chestnut v. Chestnut, 77 Ill. 346 (1875), decided under an earlier act, had been relied upon. This view of Main v. Main was approved by the Illinois Supreme Court in Brandt v. Keller, 413 Ill. $503,508,109$ N.E.2d 729, 731 (1952). That a modern court should want to avoid the effect of a precedent so heavily flavored with nineteenth century ideas regarding the proper behavior and status of women is understandable. But to say that Main v. Main ignored the act of 1874 because the act was not cited is to overlook the strong, sweeping ground of the Main case: that suits between spouses for personal torts are so objectionable that they ought not to be permitted unless the legislature clearly indicates a contrary purpose. No such clear indication can be found in the act of 1874 .

12 See Thompson v. Thompson, 218 U.S. 611 (1910); Libby v. Berry, 74 Me. 286 (1883); Willott v. Willott, 333 Mo. 896, 62 S.W.2d 1084 (1933); Comstock v. Comstock, 106 Vt. 50, 169 Atl. 903 (1934); McCurdy, Personal Injury Torts Between Spouses, 4 VILL. L. Rev. 303, 313; Note, 22 IL. B.J. 19 (1933). In Brandt v. Keller, supra note 11, an Illinois appellate court adopted the view stated in the text but was reversed by the Supreme Court. See 347 Ill. App. 18, 105 N.E.2d 796 (1952).

13 Id. at 109. This morbid prophecy was derived from Abbott v. Abbott, 67 Me. 304 (1877), a frequently cited case in which the facts were closely similar to Main but no married women's statute was involved.

14 See Thompson v. Thompson, 218 U.S. 611 (1910); Peters v. Peters, 156 Cal. 32, 103 Pac. 219 (1909); Bandfield v. Bandfield, 117 Mich. 80, 75 N.W. 287 (1898); Longendyke v. Longendyke, 44 Barb. 366 (N.Y. Sup. Ct. 1863); Lillienkamp v. Rippetoe, 133 Tenn. 57, 179 S.W. 628 (1915); Nickerson v. Nickerson, 65 Tex. 281 (1888) (common law disability based on "public policy"). The "happy home" argument was advanced, like the policy arguments in Main $v$. Main, to support a limited rather than literal construction of the statutes authorizing married women to sue and be sued which would permit them to sue their husbands for injuries to property but not for injuries to the person. To sustain this limited construction, a second argument was frequently made that the clause authorizing suits by married women should be read in the context of the other portions of the married women's statute designed to enable married women to own property and make contracts. Viewed in this light, the only suits authorized against the husband were those relating to property and contracts. 
The ancient cliches regarding the preservation of the domestic peace should not be taken literally. The judges who used them had in mind, I believe, the spectacle of a husband and wife accusing each other in public of assaults, beatings, slanders and the like. Such an unseemly and degrading display would irritate the rest of society and might, in the long run, undermine the marriage ideals and morals of the community: It was not the connubial calm of the clashing couples but the symbolic image of marriage as a great social and religious institution which the judges were seeking to preserve. ${ }^{15}$ Doubtless there was also a feeling, suggested in the quotation from Main v. Main, that such litigation might tend to lower the dignity and prestige of the courts themselves. Prior to World War I these attitudes maintained a firm hold upon the minds of most judges. ${ }^{16}$ But in the years 1914 to 1920 seven state courts broke abruptly with the older tradition and held, in cases involving wives who had been intentionally injured or killed by their husbands, that the husband was liable for the damages like anyone else. 17

To return to 1931 , suppose that at that date a purely domestic case like Buckeye v. Buckeye had come before an Ilinois court. Such a case seems to be a far cry from Main $v$. Main. There would be no unseemly quarrelling by husband and wife in public. The lawsuit would be merely an attempt to determine the husband's liability so the wife could collect from his insurer. But when such cases had come before the courts of other states, they had usually been treated as presenting inescapably the broad issue of whether the hurband

15 See Thompson v. Thompson, sipra note 14, Lillienleamp v. Rippetoe, supra nate 14. McCurdy, Torts Between Persons in Damestic Relation, 43 Harv. L. Rrv. 1034 1953 (1930), suggests that since familiarities are perminible baveen hubband and wife wilch would be impropet between strangers, some judjes may have thought that such permisible conduct would be uned $\mathbf{a}$ a basis for trivill chains.

16 Not all courts coneidered it necessary to rationalize or defend the purpowes of the common law rule. Some simply treated the clruse authorizing married women to wo in their own names as complementary to other parts of the statute. See note 14 errara. Dut prior to 1914 the actions brought by married women against their husbands (or ex-hublun) for assault, battery, fake imprisonment, etc., during coverture were uniformly unacoenfid. For cases see Annot., 6 A.I.R. 1038 (1920).

17 Johnson v, Johnson, 201 Ala. 41, 77 So. 335 (1917) (aseault and battery); Fitzpatrtck v. Owens, 124 Ark. 167, 186 S.W. 832 (1916) (killing wife); Brown v. Brown, 88 Coon. 42, 89 Atl. 889 (1914) (assault, battery and false imprisonment); Gilman v. Gilman, 78 N.H. 4, 95 Atl. 657 (1915) (ascault and battery); Crowell v. Crowell, 180 N.C. 516, 105 S.E. 206 (1920) (infecting wife with veneral diveane); Fiedler v. Fiedler, 42 Okla. 124, 140 Pac. 1022 (1914) (shooting wife in head); Proswer v. Prower, 114 S.C. 45, 102 S.E. 787 (1920) (beatins wife).

Though the opinions in these capes all take their stand upon the language of the local married women's acts, there is discernible in most of them an undercurrent of indignation of which the following statement in Brown v. Brown, supra, is a typical expression: "If a cause of action in her favor arises from the wrongful infliction of such injuries upon her by another, why does not the wrongful infliction of such injuries by her husband not give her a cause of action against hin?"' 88 Conn. at 46,89 Atl. at 891 . 
should be held liable for the wife's personal injuries caused by his negligence, 18 with or without insurance. Thus the argument that such litigation might impair the symbol of marital tranquillity was still available. Although one might suspect that the insurance aspect of the automobile accident cases would subtly influence the thinking of the judges in favor of the injured wife, the cases decided in the nineteen-twenties show indications of an opposite tendency. In several of them the judges, having pointedly referred to the presence of insurance as explaining the real purpose of the lawsuit, proceeded to decide against the plaintiff.19 The statistical evidence is also significant. Prior to the year 1932 automobile negligence suits were brought by wives against husbands in seventeen states. They were successful in four states where the courts had already decided that wives might sue their husbands for assault. ${ }^{20} \mathrm{But}$ in twelve of the remaining thirteen states they failed to secure a favorable interpretation of the local married woman's statutes. ${ }^{21}$ The one exceptional state was Wisconsin.22 Considering the limited scope implied by the wording of the Illinois statute, the obstructive influence of Main v. Main, and the discouraging trend of precedents elsewhere, it seems perfectly clear that in the year 1931.the Illi-

18 In a thoughtful study of the problem published in 1930, McCurdy, supra note 15, at 1055 , suggested that while the husband should be liable for assault or other intentional torts he ought not to be liable for automobile negligence because "husband and wife are engaged in a common enterprise for common benefit" and negligence of the husband is a normal risk of the domestic establishment. Two dissenting judges took a similar position in Katzenberg v. Katzenberg, 183 Ark. 626, 37 S.W.2d 696 (1931).

19 See Maine v. Maine \& Sons, Ltd., 198 lowa 1278, 201 N.W. 20 (1924) (suit against family corporation owned by and employing husband); Harvey v. Harvey, 239 Mich. 142, 214 N.W. 305 (1927); Newton v. Weber, 119 Misc. 240, 196 N.Y. Supp. 113 (Sup. Ct. S.T. 1922) (suggesting motive for suit was a "raid on an insurance company"); Perlman v. Brooklyn City R.R., 117 Misc. 353, 191 N.Y. Supp. 891 (Sup. Ct. S.T. 1921).

20 Penton v. Penton, 223 Ala. 282, 135 So. 481 (1931); Katzenberg v. Katzenberg, 183 Ark. 626, 37 S.W.2d 695 (1931); Bushnell v. Bushnell, 103 Conn. 583, 131 Atl. 432 (1925); Roberts v. Roberts, 185 N.C. 566, 118 S.E. 9 (1923). For a detailed chronological account of the progress of interspousal tort litigation see Haglund, Tort Actions Between Husband and Wife, 27 Geo. L.J. 697, 893 (1939).

21 Heyman v. Heyman, 19 Ga. App. 634, 92 S.E. 25 (1917); Blickenstaff v. Blickenstaff, 89 Ind. App. 529, 167 N.E. 146 (1929); Furstenburg v. Furstenburg, 152 Md. 247, 136 Atl. 534 (1927); Harvey v. Harvey, 239 Mich. 142, 214 N.W. 305 (1927); Woltman v. Woltman, 153 Minn. 217, 189 N.W. 1022 (1922); Austin v. Austin, 136 Miss. 61, 100 So. 591 (1924); Von Laszewski v. Von Laszewski, 99 N.J. Eq. 25, 133 Atl. 179 (1926); PerIman v. Brooklyn City R.R., 117 Misc. 353, 191 N.Y.Supp. 891 (Sup. Ct.S.T. 1921), aff'd mem., 202 App. Div. 822, 194 N.Y. Supp. 971 (1922); Finn v. Finn, 19 Ohio App. 302 (1924); Smith v. Smith, 29 Pa. Dist. R. 10 (1919); Oken v. Oken, 44 R.I. 291, 117 Atl. 357 (1922); Tobin v. Gelrich, 162 Tenn. 96, 34 S.W.2d 1058 (1931). A similar case in the District of Columbia was decided against the wife: Spector v. Weisman, 40 F.2d 792 (1930). During this period it was also held in two states that a wife was barred by marital immunity from suing her husband's employer for injuries due to the husband's negligent operation of a car in the course of his employment. Maine v. Maine \& Sons, Ltd., 198 Iowa 1278, 201 N.W. 20 (1924); Emerson v. Western Seed \& Irrigation Co., 116 Neb. 180, 216 N.W. 297 (1927).

22 Fontaine v. Fontaine, 205 Wis. 570, 238 N.W. 410 (1931); Wait v. Pierce, 191 Wis.

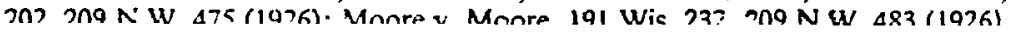


nois courts would have denied recovery in a domestic case similar to Buckeye v. Buckeye. 23

Turning to the Wisconsin law of 1931 , we see a very different picture. In Wait $v$. Pierce, ${ }^{24}$ decided five years earlier, the plaintiff, a married woman, riding in a car driven by her husband, was injured when it collided with a car driven by the defendant's employee. Alleging that the driver-husband was "jointly liable" for the injury to the wife, the defendant sought, by means of a cross complaint, to obtain contribution from him. ${ }^{25}$ The driver-husband demurred, arguing that his wife could not have maintained any action against him for her injuries. By a four to three majority the supreme court overruled his demurrer on the ground that his wife could have maintained such an action against him had she chosen to do so. The majority referred to the possibility of reaching the same result upon a narrower ground; they might have held that the defendant could compel contribution by the husband although he still enjoyed immunity to a direct suit by his wife. 26 But they rested their decision on the broader ground that the husband had no such immunity. The rule of the Wait case was followed soon afterward in Moore v. Moore 27 where, free from the complication of a third party's liability, the passenger-wife obtained a judgment against her husband for injuries resulting from his negligent driving.

In the Wait case the majority took their stand upon the ample literal meaning of an 1881 statute which provided that "any married woman may bring and maintain an action in her own name for any injury to her person or character the same as if she were sole, and any judgment recorded in such action shall be the separate property and estate of such married woman ...."28 They noted that there were no words which might be taken to indicate that its application was limited to suits against third parties, and that the section had been held in an earlier case to authorize a suit against a husband in replevin.29

${ }^{23}$ In 1952, however, the Illinois Supreme Court, with two judges dissenting, decided (reversing the appellate court) that the Illinois Married Women's Act of 1874 had authorized married women to sue their husbands for personal torts. See Brandt v. Keller, 413 Ill. 503, 109 N.E.2d 729 (1952). In that case the appellate court stated: "It is, however, significant that no court of Illinois in the seventy-seven years since the passage of the Act has considered that it gave a right to the wife to sue her husband. . . It is fair to conclude that there was a consensus of all who had to do with the matter-lawyers, judges and others-that interspousal suits for torts against the person were not allowed in this State." 347 Ill. App. 18, 24-25, 105 N.E.2d 796, 799.

24191 Wis. 202, 209 N.W. 475 (1926).

${ }_{25}$ The Wisconsin Supreme Court had adopted the rule that where there has been no moral turpitude or wilful wrongdoing, one joint tortfeasor can compel contribution by another. See Ellis v. Chicago \& N.W. R.R., 167 Wis. 392, 167 N.W. 1048 (1918).

26191 Wis. at 205,209 N.W. at 476.

27191 Wis. 232, 209 N.W. 483 (1926).

28 Wis. Laws 1881 ch. 99 . See now Wis. Stat. $\$ 246.07$ (1959).

29 Carney v. Gleissner, 62 'Vis. 493, 22 N.W. 735 (1885). 
They referred to the history of Wisconsin statutes relating to married women as evincing a declared policy of the legislature to remove common law disabilities. ${ }^{30}$ They referred to prior judicial opinions which stated that such statutes should be liberally construed. 31 The argument that suits for personal torts between husband and wife would destroy domestic tranquillity was discussed with sceptical coolness. ${ }^{32}$ In any event, it was observed, this was an argument of legislative policy which had apparently made no impression upon the legislature. 33

Let is return now to Buckeye v. Buckeye in which, it will be recalled, the injured wife and her defendant husband were both domiciled in Wisconsin. In the Wait case the court had faced a problem of statutory construction: did the statute authorizing suits by married women extend to the case of a wife suing her husband for a personal tort? In the Buckeye case the court again faced a statutory construction problem of only a slightly different nature: did the statue extend to the case of a suit between a Wisconsin couple for injuries suffered by the wife in Illinois ? ${ }^{34}$ The statute spoke generally of "any married woman" and of "any injury to her person or character," but these all-embracing terms obviously required some qualification. The statute needed to be construed in the context of subject matter and purpose. The majority opinion in the Wait case had emphasized the declared policy of the Wisconsin legislature to remove the common law disabilities of married women; the Buckeye case raised the question: which married women? Surely the obvious answer should have been married women who lived in Wisconsin and who were voting, tax-paying members of the Wisconsin political community. This answer would not, of course, have been exhaustive. There might still be additional border-line cases, such as Wisconsin married women living apart from hus-

30191 Wis. at 208-12, 216, 209 N.W. at 477-79, 480.

31 Id. at 207, 208, 212, 209 N.W. at 477, 479.

32 Id. at 216, 209 N.W. at 480 . "[W] find no likelihood of the social order being shattered by holding that she has a right of action for injuries done to her person and character as well as to her property whether committed by her husband or third parties. ...." None of the judges mentioned the insurance aspects of the problem. But when four months later the same court held that a child under fourteen years could not maintain an automobile negligence suit against his father, Crownhart, J., dissenting, brought the insurer's liability into the open, saying, "And if he [the parent] is thoughtful enough to insure against misfortune due to his negligence to the public at large, must the court step in and deny the infant member of his family the same chance in life as is possessed by the public? I think not." Wick v. Wick, 192 Wis. 260, 268, 212 N.W. 787, 790 (1927).

33191 Wis. at 212, 209 N.W. at 479.

34 For further discussion of choice-of-law problems as problems of statutory construction, see Currie \& Lieberman, supra note 7, at 1-9, 41-45; Hancock, Three Approaches to the Choice-of-Law Problem: the Classificatory, the Functional and the Result-Selective, in Twentieth Century Comparative and Conflicts law, Legal Essays in Honor of Hessez E. YNTEMA, 365, 367, 371, 375, 377 (1961); Book Review, 14 U. TOR. L.J. 129, 130 (1961). 
bands domiciled elsewhere or married women residing35 temporarily in Wisconsin. The Buckeye case, however, did not demand answers to all of these questions.

Since the defendant's insurer ${ }^{36}$ had taken the necessary steps to bring the Illinois common law rule before the court, it would have been appropriate to inquire into the relation between the social objectives of that rule and the facts of the case. We have already considered these objectives and none of them appear to be involved in the present case. If the rule was really supposed to pacify quarrelling couples by drawing the curtain of privacy over unfortunate behavior, it could only have been meant to benefit couples resident in Illinois. If, as has been suggested, the rule was based upon a judicial belief that litigation of a certain type between spouses would tend to undermine the community's ideals and detract from the dignity of its courts, then the rule would normally be applied to bar such litigation from Illinois courts no matter where the parties lived. The same result would obtain if the rule was believed to serve a useful purpose in preventing collusive law suits, unfair to the insurer and engendering biased testimony. ${ }^{37}$ Thus, although the injury occurred in Illinois, none of the foregoing policies suggests that the common law rule ought to have been applied by the Wisconsin court in the Buckeye case. It is a rule designed neither to encourage nor discourage certain conduct in Illinois, 38 nor to allocate the loss resulting from injury to persons or property located there.

We are now in a position to give at least a short answer to the question posed at the outset: why was Buckeye v. Buckeye overruled? Our analysis shows that there was no conflict at all between the Illinois policies for the common law

35 Where not qualified by the word "temporarily" or some similar expression, the words "residing," "resident," and the like are used in this article with the general meaning of "domicile," as that term is usually defined. But the reference is only to the simple standard case of the person whose contacts like home and occupation are all with one state. The peculiar cases of a person having substantial contacts with two states or no contacts with any state would, in a functional analysis, naturally require separate treatment.

36 To obtain a realistic view of this and similar cases we must remember that (1) the real motive for the suit is the desire to obtain a money judgment for the wife which will be payed by the husband's insurer; (2) that the husband's defense is being conducted by the insurer's attorney.

37 "Indeed the strongest argument against such actions is not disruption of domestic tranquillity, but the danger of domestic collusion." McCurdy, supra note 15, at 1052-53.

${ }^{38}$ A state government may purposely encourage certain supposedly desirable activities within its borders by enacting or (judicially) evolving laws specially protecting persons engaged in those activities from legal liabilities incurred while so engaged. Thus police officers may be relieved, in particular circumstances, from legal responsibility for unlawful arrests or false imprisonment. Charities are sometimes accorded a limited immunity for torts committed in the course of their beneficent pursuits. There was no analogous purpose, however, in the immunity given by Illinois law against suit by the tortfeasor's spouse. That immunity was not given in order to encourage people to marry or to make motoring together attractive to married couples. 
rule and the Wisconsin statute of 1881 . It was what conflict-of-laws technicians call a "false-problem case"; 39 there were good policy reasons for applying the Wisconsin statute and none at all for applying the Illinois law. Yet the court held that the suit of the Wisconsin wife against her Wisconsin husband must be dismissed because "the law governing the creation and extent of tort liability is that of the place where the tort was committed." 40 It is not surprising, therefore, that the court which overruled the Buckeye case in 1959 remarked: "strong reasons of public policy exist for supplanting such a rule by a better one which does not unnecessarily discriminate against the citizens of our own state."41

Our account of the reasons for the overruling of Buckeye v. Buckeye, though pointed, is neither historically nor analytically complete. In particular, the curious reader will feel that some further explanation is needed of the influences or arguments which led the Wisconsin court astray in the first place. How, only five years after its bold and controversial decision of the Wait case, was the court induced to deny the benefits of that decision 42 to a married woman citizen of Wisconsin? Once the logical and legal bases of the Buckeye case have been explored, the reader will look for a somewhat richer and more detailed account of the process by which, during the intervening twenty-eight years, the decision was undermined and eventually overthrown.

39 For similar examples of false-problem cases which, functionally analyzed, present no real conflict of domestic laws or policies, see Currie, Survival of Actions: Adjudication versus Automation in the Conflict of Laws, 10 STAN. L. REV. 205, 239, 247 (1958); Hancock, supra note 34, at 368, 376; Traynor, supra note 7.

40203 Wis. at 250,234 N.W. at 342.

41 Haumschild v. Continental Cas. Co., 7 Wis. 2d 130, 138, 95 N.W.2d 814, 818 (1959).

Practically speaking, the principal effect of the Buckeye case had probably been that married women resident in Wisconsin but injured in states retaining the common law disability received little or nothing in the settlement of their claims by the insurers. See 2 HARPER \& JAMES, TORTS 782 (1956).

To secure adequate protection to the injured citizen spouse it is essential that she (or he) should have not only a right of recovery against the tortfeasor spouse but also an expeditious and direct remedy against the insurer. Since 1925 Wisconsin law had progressively improved this remedy so as to make it more effective than those available in neighboring states. See Comment, 1953 WIS. L. ReV. 688. In these circumstances the courts of Wisconsin and other states have had to determine in marginal cases the interstate coverage of the Wisconsin law fixing the rights and remedies of the injured person against the insurer. The general problem is closely related from the practical point of view to that of this article. See 1959 WIs. L. REv. 159; Risjord, Conflict of Laws Applicable to the Standard Automobile Liability Policy, 1957 WIs. L. Rev. 586, 606-11; Speidel, Extraterritorial Assertion of the Direct Action Statute, 53 Nw. U.L. Rev. 179 (1958); Note, 74 HARv. L. Rev. 357, 374-92 (1960).

42 In the Buckeye case the court refused to extend the benefits conferred by the Wisconsin statute to a Wisconsin citizen because her injury occurred in Illinois. The statute did not infringe upon any applicable policy of Illinois law. Was the decision, therefore, a "denial of equal protection" within the meaning of the fourteenth amendment? For a general discussion pointing to an affirmative answer see Currie \& Schreter, Unconstitutional Discrimination in the Conflict of Laws: Equal Protection, 28 U. CHI. L. REv. 1, 29-37, 46-51 (1960). 


\section{The "Buckeye" Case as an Exercise in Classification}

Although the opinion in Buckeye v. Buckeye is not a long one, it would be unfair to call it superficial. But the court did not approach the case as a problem of statutory construction involving consideration of the policies of the Wisconsin and Illinois laws. That the action would be maintainable under Wisconsin law was simply taken for granted. No reference was made to the statute of 1881 nor to the Wait case and its vigorous arguments for emancipating married women. 43 Three Illinois cases were cited, but all we are told is that at the time of marriage the common law merged the wife's legal personality with that of her husband so that all her causes of action against him were extinguished. The reasons, ancient or modern, for such a doctrine are not discussed; presumably the court was not concerned with them.

The court's primary emphasis was not upon the domestic laws or their policies, but rather upon three standard choice-of-law principles which provided the doctrinal framework for the reasoning of the opinion. The legal consequences of marriage as to property (except interests in land) should be governed by the law of the matrimonial domicile; matters of tort liability should be governed by the law of the state of injury; matters pertaining to the remedy should be governed by the law of the forum. ${ }^{44}$ Having adopted these basic principles, the court was confronted by the familiar task of classifying or characterizing the domestic rules of Wisconsin and Illinois law. Were they rules concerning the effect of marriage on property rights, rules of tort liability, or rules relating to the remedy? In other words, the court defined its problem, not as one of construing the domestic rules in their application to the facts but rather as one of fitting the domestic rules into the categories of the choice-of-law principles.

Every lawyer knows that the manner of stating the "issues" of a controversy may vitally affect the outcome. What shall we say regarding the formidable conceptual machinery of these three choice-of-law principles and their inherent problem of classification? Did they prevent the court from reaching the conclusion to which a functional analysis emphasizing domestic policies would point? This is an important question for conflict of laws methodology in general, and is not to be casually answered.45 As compared

43 There is no reason, however, to suspect that the judges who decided the Buckeye case disapproved of Wait v. Pierce. When the Buckeye decision was rendered the three judges who dissented in Wait v. Pierce had left the court. And only a few months later the judges who had decided the Buckeye case expressed approval of Wait v. Pierce in Fontaine v. Fontaine, 205 Wis. 570, 577, 238 N.W. 410, 412-13 (1931).

44 For the court's own language see note 50 infra.

45 See Hill, Governmental Interest and the Conflict of Laws-A Reply to Professor Currie, 27 U. CHI. L. REv. 463, 481-83, 502-04 (1960), apparently suggesting that traditional choice-of-law principles do not hinder the recognition and implementation of the policies of domestic rules. To the contrary see Currie, The Verdict of Quiescent Years: Mr. Hill and the Conflict of Laws, 28 U: CHI L. Rev. 258, 281-85, 295-96 (1961). 
with a functional analysis, the classificatory formulation reduced the domestic laws and policies to a subordinate level; but it ciearly did not exclude them from all consideration. Moreover the categories of legal rules or relations forming part of the three choice-of-law princlples were quite broad and flexihle. The judges were left with considerable leeway to achieve a classification which would be guided by a consideration of the policies of the Wisconsin and Illinois rules. Had they concluded after considering reasons set out above that the Wisconsin statute ought to control. they could have reached this result via the appropriate cnoice-of-iaw principle by classifying the domestic rules as pertaining to the effect of marriage on the existing property rights of the spouses. 40 The same sensible result could have been reached. though a trifle less directly, by classitying the illinois rule as one which merely denied a remedy. llinois law neither conferred upon husbands the privilege of injuring their wives nor made such injury lawful: it took away the wife's right of action. Hence. it might have been argued that such a law merely affected the remedy. ${ }^{47}$ An even stronger argument for such a classincation might have been derived from a group of cases which had held that where a plaintult dies after the commencement of an action. the law of the torum should determine wnetner the action abates or proceeds since this question relates to tne remeay.40

46 Immediately prior to her marriage the plaintiff wife had a right of action against the defendant whether we look, to the law of Wisconsin or that of Illinois.

${ }^{47}$ From a strictly functional point of view this argument is entirely fallacious. The fllinois common law rule should be disregarded because none of its basic policies would be served by abolying it to the facts of this Darticular case. But the choice-of-law rule governing remeulat matters requires that the foreign law should be disregarded in all cases. And the circumstance that a rule of foreign law denies a right of action for an unlawful injury is not a sufficient reason for disregarding that rule in all cases. Had the parties been domiciled in Illinois it would have been quite wrong to disregard the Illinois rule. See text at note 141 infra. In an ideal system of conflict of laws the rule that the law of the forum governs remedial matters would probably be discarded completely. If retained at all, its function would be carefully and restrictively defined in some such manner as was suggested by Cook. (See COOK. Logical AND Legal. Basfs of THE CONFlict of Laws ch. 6 (1942). At the present time, however, it nor intrequently happens that although the facts of a case are so signifcantly connected with the forum that the judges feel sure the local law ought to be applied, some antiquited territorialistic choice-of-law principle appears to prohibit that result. It then becomes necessary to make use of the remedial classification as an "escape device" for justifying resort to the law of the forum. This judicial technique, though regrettable if only because the real reasons for the decision are obscured, is more or less inevitable so long as judges are expected to force their decisions into the ancient moulds of choice-of-law principles. See Cavers, $A$ Critique of the Choice-of-law Problem, 47 HaRv. L. REv. 173, 185 (1933); Currie, supra note 39, at 209-17.

48 Baltimore \& O.R.R. v. Joy, 173 U.S. 220 (1899); Martin v. Wabash R.R., 142 Fed. 650 (1905). In these cases the plaintiff was a resident of the forum; the remedial classification enabled the court to give him the benefit of the local law which would permit his suit to proceed although the law of the place of injury would not. Gordon v. Chicago, R.I. \& Pac. Ry., 154 Iowa 449, 134 N.W. 1057 (1912) is a similar case in which the plaintiff was probably a resident of the forum. But Austin's Adm'r v. Pittsburgh C.C., \& St. L. Ry., 122 Ky. 304, 91 S.W. 742 (1906) illustrates the dangers of such devious devices as the remedial classification in the hands of judges who do not understand them. The plaintiff was resident 
Yet we know that these alternative classifications, however obvious they may be to the conflict-of-laws technician, were brushed aside by the Wisconsin court in favor of a chain of reasoning which led to the application of the Illinois rule barring the action. The remedial classification was barely mentioned and rejected. The marital property classification was apparently accepted, but the tort liability classification was considered to be absolutely inescapable as well. Thus the court was faced with the prospect of a head-on collision between two choice-of-law principles, a juristic phenomenon of an exquisite impossibility comparable to the ceaseless oscillations of the renvoi. To avoid this impasse the court seized upon a fourth choice-of-law principle referring the effect of marriage upon the spouse's rights in land to the law of the situs and announced that "the same reasoning applies to the situation presented here, and requires the conclusion that the effect of plaintiff's marriage upon her cause of action is to be determined by principles of conflict of laws applicable to real property rather than by those applicable to other property." 49 Treating Illinois as the situs of the plaintiff's "property," the court inquired what an Illinois court would have done with the instant case. Concluding that an Illinois court would have held that the plaintiff's cause of action was extinguished by her marriage, the Wisconsin court did likewise.

Why did the judges not fix upon one of the alternative classifications suggested to reach a result more consonant with the policy of the Wisconsin statute? Apparently they had not formed any clear, independent conception of that policy as applied to the facts of the Buckeye case. This is not surprising, for the processes of thought engendered by standard choice-of-law principles have a strong tendency to overlook the policies of domestic rules and to divert the minds of judges toward abstract and irrelevant issues. The problem of the Buckeye case, as it appeared when presented in the doctrinal choice-of-law framework, 50 was to assign the combined rules of Ilinois and Wisconsin law (or "the juridical question" raised by these rules) to one of three broad categories. Thus separate consideration of the Wisconsin statute or its policy was deprecated. The choice-of-law framework required the judges to classify the domestic rules in an abstract combination such as "capacity to sue spouse"

and injured in Indiana where an action for personal injury would have terminated upon his death. After prudently filing suit in Kentucky, he died; applying Kentucky law, the court continued his action. This decision does violence to one of the most basic of choice-of-law policies. See text at note 141 infra.

49203 Wis. at 252,234 N.W. at 343.

so "It is not seriously in dispute that the law governing the creation and extent of tort liability is that of the place where the tort was committed.... It is also the rule that a liability to pay damages for a wrong may be discharged or modified by the law of the state which created it. . . . On the other hand, with respect to the legal consequences of marriage, both as to the status of the parties and as to all their property interests except interests in land, the law of the matrimonial domicile governs. ... It is also clear that the law of the forum governs all matters relating to the remedy, the conduct of the trial, and the rules of evidence." Id. at $250,234 \mathrm{~N}$.W. at 342-43. 
or "marital immunity." 51 Moreover, the very breadth of two of these categories (torts and matters relating to the remedy) carried a strong suggestion that the policy of a particular domestic rule was of no moment. Either of these categories would normally have embraced many different rules with many different policies.52 The judges' attention was focused upon a highly abstract, taxonomic puzzle; the real problem of construing the Wisconsin statute and harmonizing that construction with the Illinois law faded into the background.

Judges are rarely conscious of this diversionary effect of choice-of-law principles. Such principles carry with them a superficially beguiling sense of rightness. One may think, for example, that the law of the state of injury should determine tort liability because that state has an interest in prescribing rules of conduct within its borders. 53 This is a sound and sensible principle; how can it lead us astray? Although such a formulation is a helpful guide for simple cases involving prescribed rules of conduct, as an intellectual tool for dissecting a case like Buckeye v. Buckeye, involving other important factors, it is cumbersome, crude and misleading.

51 If we think about the facts and the domestic rules in the Buckeye case, without having in mind any choice-of-law principles, the problem appears to be one of choosing which of the two domestic rules is to be followed. We can examine each rule separately, identify its policy, and inquire whether that policy would be served by applying the rule to the present case. But the moment we introduce choice-of-law principles into our thinking the form of the problem appears to have changed. We are now confronted with three broad categories, each pointing to a particular state and so to a single domestic rule, provided the rule fits the category. How can we utilize this categorical machinery to choose between the two different domestic rules? Our problem is basically a problem of choice; therefore, if we make a classification which adopts one rule as the rule of decision we must necessarily reject the other rule. Hence it appears that we must assign both rules (or the abstracted "legal question" they involve) to one of the three broad categories in order to select one rule and discard the other, e.g., if we were to assign them to the "legal-consequences-of-marriage" category the Wisconsin rule would be the one selected. But when we classify these domestic rules in such a combination we emphasize their similarities and obscure their differences, including their respective policies which, as we have seen, are different. Thus, in the process of thinking out the selection problem as one of following choice-of-law principles, the contrasting policies of the domestic rules are effectively obscured and tend to drop out of the reckoning entirely.

Of course, this train of thought would be followed by the judges only if they took the choice-of-law principles seriously and tried to use them as conceptual tools for thinking about and deciding the case. That they did take those principles seriously and use them in that way is indicated by (1) their statement of the principles as the basic framework for the adjudication, (2) the complete absence from the opinion of any reference to the Wisconsin statute or cases or the policy thereof, and (3) the result reached.

52 The court ruled that the law of the place of injury should govern the discharge or modification of tort liability. For this broad proposition the only authority cited was an English case of 1870 holding that an act of "General Pardon, Indemnity and Oblivion" passed by the legislature of Jamaica would be recognized as a discharge of civil liability for acts of assault and false imprisonment in that colony. Phillips v. Eyre, L.R. 4 Q.B. 225 (1869), L.R. 6 Q.B. 1 (1870). A choice-of-law principle which can embrace both this Jamaican statute and the Illinois rule of marital immunity f $r$ personal torts would appear to attach little significance indeed to the policies of domestic rules.

53 See note 38 supra. 
When the judges decided that the domestic rules were embraced by both the tort and marital property categories, they succeeded in raising a false issue of really substantial proportions. What should be done to resolve a "conflict of conflict rules" of this nature? Never losing faith in the choice-oflaw system, however, the judges again turned to it for a solution and came up with the fantastic analogy to interests in land. And so, following this analogy most carefully, they reached the final stage where it became necessary to decide what an Illinors court would have done if the plaintiff had prosecuted her action in that state. The extraordinary fexibility of the choice-of-law machinery is such that even at this stage the court might have chosen the Wisconsin law by concluding that since Illinois had no interest in applying its prohibitory. rule to Wisconsin couples, the Illinois court would have followed the Wisconsin statute. But by this time the court had lost all sense of the policy of either law.

How, then, shall we say the court was led astray? It was led astray by the standard choice-of-law principles upon which it relied to obtain a sound decision. These principles presented no insuperable obstacle to such a decision; quite the contrary. Had the judges believed zealously in "women's rights" or approached the case with the parochial notion (not unknown in older lawyers) that the law we know best is best, the choice-of-law apparatus could have easily accommodated a different result. However, these judges knew that many states had never permitted suits between spouses and that such suits had come only recently to Wisconsin by a bare majority vote of the court. They considered the Ilinois law without any prejudice and tried to think out a solution to the case in terms of orthodox choice-of-law concepts and principles. Because these concepts and principles took no account of the policy thrusts of domestic statutes and confronted the court with false issues which effectively concealed them, the judges ended up with a result which has proven to be unsatisfactory.

The tendency of choice-of-law principles to divert the mind from practical ends to barren issues of classification or renvoi is clearly evident in the first law review comments upon the Buckeye case. The writers of these comments were sufficiently familiar with those principles and the techniques of manipulating them to identify and describe the three alternative choice-of-law routes which we have discussed. Some emphasized the marital property classification, others stressed the remedial (or procedural) classification 54 and one writer noted the possibility of arguing that an Illinois court would have allowed recovery in the instant case because the common law "merger" rule should only apply to couples domiciled in Illinois. 55 Though clearly aware of the technical

54 Note, 31 Colum. L. Rev. 884 (1931) (remedial classification); Note, 44 HaRv. L. Rev. 1138 (1931) (marital property classification); Note, 29 MICH. L. REv. 1072 (1931) (remedial and marital property classifications); Note, 79 U. PA. L. REv. 804 (1931) (remedial and marital property classifications); Note, 6 WIS. L. REV. 103 (1931) (remedial classification).

ss Note, 6 Wis. L. REv, 103 (1931). 
bases for the application of the Wisconsin statute, none of the commentators was able to bring forward a persuasive reason for the Wisconsin court to have taken that course. One, after stating the alternative possibilities, grudgingly approved the decision: "the rule applied by the court is less involved and more easily applied...."s6 Two of them took up a stance of complete neutrality.57 A fourth adopted a result-selective approach, 58 the court had "missed a good opportunity ... to avoid the consequences of the artificial common law concept of the identity of husband and wife." 59 Perhaps the most remarkable was one who would have liked to see the domiciliary law applied in order to achieve "greater consistency" in the classification of tort choses in action as movables rather than immovables. ${ }^{0} 0$ Only one even mentioned the boldy progressive Wisconsin decision in Wait $v$. Pierce. ${ }^{61}$ None ventured to suggest that the Wisconsin statute might have been enacted for the benefit of Wisconsin residents or that the Buckeye decision might some day be reconsidered.

Cases involving the same pattern of facts ${ }^{62}$ and laws as Buckeye v. Buckeye came before the courts of North Carolina and Alabama in the same year and three years later before the Supreme Court of New Hampshire. As in the Buckeye case, the policy and scope of the domestic domiciliary statutes became virtually invisible when the judges contemplated their problem through the murky lenses of the choice-of-law system. Various pseudo-issues generated by the system were discussed, but the defendants won all three cases. The plaintiffs did not argue, as in the Buckeye case, for a direct application of the law of the domicile but tried to reach it by way of renvoi or one of the escape devices. ${ }^{63}$ In the North Carolina case 64 the argument of "public policy" was raised against the court's resort to the common law prohibition of the state of injury; this had the disadvantage of focussing attention upon the moral symbolism of the rule rather than the problem of its coverage. The court replied that "prohibited marriages, wagers, lotteries, racing, contracts for gaming or the sale of liquor"6s might be contrary to the settled public policy

56 Note, 29 MiCH. L. REv. 1072, 1073 (1931).

57 Note, 79 U. PA. L. Rev. 804 (1931); Note, 6 Wis. L. REv. 103 (1931).

58 An approach to choice-of-law problems which frankly selects whichever domestic rule appeals to the judge (or commentator) as the most desirable, just or convenient. For discussion and reference, see Hancock, supra note 34, at 372, 376.

59 Note, 31 Colum. L. Rev. 884, 885 (1931).

60 Note, 44 Harv. L. REv. 1138, 1139 (1931).

61 Note, 29 Mich. L. REv. 1072, 1073 (1931).

62 The facts of these three cases differed from Buckeye v. Buckeye in one point: the parties were married before the wife sustained her injuries whereas in the Buckeye case they did not marry until after the accident and the filing of the suit.

63 That is, either the remedial classification (see note 47 supra) or the public policy doctrine. The use of the public policy doctrine as an escape device to avoid the effects of choiceof-law principles has been noted and discussed by Cavers, supra note 47, at 183-84; Paulsen \& Sovern, "Public Policy" in the Conflict of Laws, 56 Colum. L. REv. 969 (1956).

64 Howard v. Howard, 200 N.C. 574, 158 S.E. 101 (1931).

65 Id. at 580, 158 S.E. at 104. 
of the forum-but not the rule in question. In the Alabama case 66 the injured wife had the misfortune to encounter a stray dictum from that monument to territorialism, Alabama Great Southern R.R. v. Carroll, ${ }^{67}$ but gamely tried to get back to the Alabama rule by way of renvoi from the law of the state of injury (Mississippi). The judges concluded that a Mississippi court would never countenance a suit by an Alabama married woman against her husband since it would then be discriminating against Mississippi wives. Nothing was said about the discrimination involved in the Alabama court dismissing the Alabama wife's suit because she happened to be hurt in Mississippi.68 A vigorous effort to establish a remedial classification was made in Gray v. Gray, ${ }^{69}$ the New Hampshire case, with the argument that the law of the state of injury (Maine) merely prohibited suit but surely did not render the injurious act of the husband lawful. The court ingeniously foiled this attempt to guide it to a sensible result by indirection. A Maine case had held that after divorce a wife could not sue her husband for false imprisonment during coverture; this showed, said the New Hampshire court, that "the theory adopted there is not merely that there is a prohibition of suit, but that the acts complained of do not give rise to any cause of action. There has been no breach of legal duty."70

\section{A New Domiciliary Choice-of-Law Principle Emerges}

It was Gray v. Gray, however, which provoked the first critical note regarding this group of cases, a note sounded by a student writer in the Yale Law Journal in 1935. Arguing for a functional approach to the question, "what law governs," he contended that if the state of the parties' domicile "does not fear discord among the families within its borders, then it hardly seems to be the concern of other states...."71 Two years later, Stumberg adopted this line

66 Dawson v. Dawson, 224 Ala. 13, 138 So. 414 (1931), approved in Note, 16 MinN. L. REv. 705 (1932).

6797 Ala. 126, 11 So. 803 (1892).

68 See note 42 supra.

6987 N.H. 82, 174 Atl. 508 (1934). The opinion contains an elaborate discussion of the possibility of renvoi to the law of New Hampshire, a line of reasoning which the court declined to adopt on several grounds. In his celebrated article, Renvoi Revisited, 51 HARv. L. REv. 1165, 1206 (1938), Dean Griswold suggested that, had the court looked to the "whole law" of Maine, "it might well have been decided that the Maine rule was one of local policy only, which the Maine court would apply only to Maine husbands and wives, on the ground that it was designed to prevent domestic strife in Maine, a matter of concern to Maine alone. ... [T] [Therefore, it might have concluded that a Maine court would hold the capacity to be governed by New Hampshire law and thus allow the suit." Hence a functionally sound result might have been reached by way of renvoi. But if the Maine policy was to exclude all suits against spouses from Maine courts because of the danger of bias and collusion the application by the New Hampshire court of the "whole law" of Maine would have produced a dismissal. The "whole law" construction of choice-of-law principles with its renvoi corollary sometimes arrives indirectly at a functional result, sometimes does not.

7087 N.H. at 87, 147 Atl. at 59-60 (1934).

7 Comment, Functional Aprlication of Conflict of Law's Rules in Torts Cases, 44 YAlE L.J. 1233, 1235 n.14, 1239 (1935). 
of reasoning in his textbook and suggested that "the domiciliary law might well be applied since for other purposes concerning domestic relations it is so applied."72 In 1942 Rheinstein marshalled in support of the same conclusion the further argument that "problems of family relations should, as far as possible, be determined by one and the same law irrespective of where certain events take place...."73 Later in the year the formidable Walter Wheeler Cook concurred: "[1]t seems reasonably clear that the question of policy is one for the law of the domicile rather than that of the place of wrong."74

Viewed in the light of our investigation of what went wrong in Buckeye $v$. Buckeye, these critical suggestions, though helpful, do not get to the root of the problem. True, the policy of domestic capacity rules is considered but it is a fuzzy, abstract policy, a policy for rules which deny the wife a remedy and a policy for rules which give her a remedy (if such a thing be really conceivable). There is no suggestion that judges should come directly to grips with the diverse domestic rules and their purposes; it is assumed that these must be handled indirectly through the medium of a choice-of-law principle of the standard form linking a category of legal rules (capacity to sue spouse) to a jurisdiction where defined events have occurred (the domicile). But this choiceof-law principle, like all others of the standard form, has the fatal flaw diagnosed and described by Cavers. 75 It is conceptually so crude and indiscriminating that, while indicating a satisfactory solution for one case, it compels the court to approve an unwelcome result in another. Suppose a wife, resident in Illinois, were to bring suit in Wisconsin against her husband for injuries due to his negligent driving there; should the Wisconsin statute be held to cover her case? Perhaps it should. Personal injuries to people passing through Wisconsin present a serious problem. They must have immediate medical care and other services provided by local residents who must in turn be compensated.76 The Wisconsin court might well decide to apply its statute regardless of the law or policy of Illinois against interspousal suits. Yet this reasonable conclusion would te flatly inconsistent with the domiciliary choice-of-law

72 StUmberg, Conflict of Laws 187 (Ist ed. 1937).

73 Rheinstein, Michigan Legal Studies: A Review, 41 Mich. L. Rev. 83, 97 (1942).

74 Cook, supra note 47, at 250.

75 Cavers, supra note 47 , at 178-82, 189-91, 194, 204-05. The point is put in a nutshell at pp. 181-82: "A 'positive' methodology charged with ascertaining a rule of law capable of working satisfactory results in two cases wherein 'facts' decisive . . . of the judgments reached (the applicable domestic laws) may be diametrically opposed is set an impossible task."

76 Since a judgment against the defendant spouse would normally be paid by the liability insurer, the case would be not unlike that of an injured employee covered by workmen's compensation insurance. See Pacific Employers Ins. Co. v. Industrial Acc. Comm'n, 306 U.S. 493 (1939). The Louisiana court would apparently apply its rule that although the defendant spouse has immunity the insurer has none to a case where the injury occurred there. See Burke v. Massachusetts Bonding \& Ins. Co., 209 La. 495, 24 So. 2d 875 (1946) (dictum). See also Watson v. Employers Liab. Assur. Corp., 348 U.S. 66, 72, 73 (1954); Carroll v. Lanza, 349 U.S. 408, 413 (1955). See also note 77 infra. 
principle put forward by the commentators to deal with the Buckeje $y$. Buckeye situation. Such choice-of-law principles offer the courts a ridiculous "package deal"; though the cases be diametrically different, the adjudication of one automatically settles the result in the other. ${ }^{77}$

None of the distinguished commentators suggested that the judges should have approached the Buckeje case as a problem of construing the Wisconsin statute in the light of its subject and purpose. None of them suggested that the court might have been misled by the existing array of standard choice-oflaw principles. Instead, they proposed to add to that array one more choiceof-law principle of the same beguiling form. The conceptual machinery of choice-of-law, with its overlapping, "package-deal" categories, its pointless and distracting problem of classification, its mysterious possibility of renvoi and its haphazard handling of domestic policies was not to be discarded in favor of a fresh approach. The existing machinery was to be patched up with a new "package-deal" choice-of-law principle. 78

\section{The Law of the Place of Wrong Rejected at the Domicile}

While the critics were forging a new choice-of-law principle, the courts handed down a series of decisions containing the seeds of deviation from Buckeye v. Buckeye. These decisions were concerned with the situation in which the plaintiff wife, having been injured in a state where suits against husbands were permitted, brought her action in the state of the domicile where the common law disability prevailed. The most renowned case of the group was Mertz v. Mertz,79 decided by the New York Court of Appeals in 1936. The parties resided in New York which had retained the common law

77 A forthright functional analysis, quite independent of orthodox choice-of-law principles, was put forward by Freund in 1946 in Chief Justice Stone and the Conflict of Laws, 59 HARV. L. REV, 1210, 1223-24. He suggested that in the Buckeye type of case the court of the domicile might properly apply its own law because (1) an examination of the case law of the state of injury showed that the courts there did not regard the instant case as falling within the scope of their domestic rule or (2) an examination of the policies of that rule pointed to the same conclusion. Regarding the converse problem discussed in the text, he explicitly rejected the "package deal" result in these words: "[T] The interest of B [state of injury] might not necessarily have to yield to that of the domicil [sic], for the place of injury may have an interest in the financial accountability of the defendant in relation to expenses incurred in B, particularly in view of the widespread use of liability insurance, and the policy of state A [domicile] might be recognized as attenuated and anachronistic and property to be limited to domestic occurrences in the event of such a clash of interests. This is admittedly only an arguable, not a clearly indicated, solution. At all events it should not be a mark of intellectual dishonesty to choose the law of one state when it imposes liability and not when it imposes no liability; its competitive position may be stronger in the one case than in the other, when the interests of the states are compared." Freund, supra at 1224.

78 Because of its very abstract generality, the commentators' suggestion that the liability of one spouse to be sued by the other should be determined by the domiciliary law was not as persuasive as it might have been. "Such an argument," remarked Judge Goodrich, "does not make much of an appeal." (Goodrich, Five Years of Confict of Law's, 32 VA. L. REv. 295,321 (1946).) Perhaps this explains why it was not judicially recognized until 1957.

79271 N.Y. 466, 3 N.E. 20597 (1936). 
rule but the accident had occurred in Connecticut, the first state to abandon that rule. Whether the purpose of the New York rule was the prevention of unsavory suits or the preservation of connubial concord, or both, it was clearly incompatible with a suit between resident spouses going on in a New York court. On the other hand, it was certainly arguable that the Connecticut statute was designed to give a right of action to any married woman who was injured in that state. Finding the laws and policies of the two states in conflict, the court might normally have been expected to choose its own. But how could this result be reconciled with orthodox choice-of-law principles? Unlike the court in the Buckeye case the New York court seemed to know where it was going and manipulated the machinery accordingly. "The law of the forum," it said, "determines . . the capacity of parties to sue or to be sued, the remedies which are available to suitors and the procedure of the courts." In the present case, "it recognizes the wrong, but denies remedy for such wrong by attaching to the person of the spouse a disability to sue." 80 In addition to this remedial classification the court invoked the "public policy" doctrine, always a useful escape device for avoiding awkward choice-of-law principles.

Conflicts decisions which make use of the "escape devices" have two disadvantages; the device which they use may be given an unduly expansive definition, ${ }^{81}$ and in any case there is a serious failure to articulate the real basis for the decision. The first disadvantage may be seen in the reasoning of the Mertz case. Eighteen years earlier in Loucks v. Standard Oil Co.82 Judge Cardozo had announced his famous narrowing definition of public policy in conflict of laws: the courts "do not close their doors, unless help would violate some fundamental principle of justice, some prevalent conception of good morals, some deep-rooted tradition of the common weal."83 Legal scholarship of that date, concerned more with dogma than discovery, 84 had not yet discerned the doctrine's escape-device function. Pressed with the argument that this sententious language of Cardozo could scarcely be applied to the anachronistic married women's disability, the majority in the Mertz case retorted that "when we speak of the public policy of the State, we mean the law of the State, whether found in the Constitution, the statutes or judicial records."8s This incautiously broad definition with its parochial implication that deci-

80 Id. at 473,3 N.E.2d at 599-600.

81 See Paulsen \& Sovern, supra note 63, at 984-85, 997, 1016.

87224 N.Y. 99,120 N.E. 198 (1918). For a recent functional analysis of the problems of the Loucks case see Currie \& Schreter, supra note 42 , at 47.

${ }^{83} \mathrm{Id}$. at 111,120 N.E. at 202.

34 Compare Judge Beach's doctrinal homily, Uniform Interstate Enforcement of Vested Rights, 27 YALE L.J. 656 (1918), with the realistic explanations offered in the articles cited in note 63 supra.

85271 N.Y. at 472, 3 N.E.2d at 599. 
sions in conflicts cases must always be squared with New York domestic lau, led two judges to dissent and provoked a barrage of law review criticism. Unfortunately, eight of the ten commentators ${ }^{86}$ in their zeal completely overlooked the significance of the fact that the parties were residents of New York although it was mentioned three times in the opinion. Shorn of its sweeping generalities and confined to its facts, the decision of the majority was exactly what one would expect from a functional analysis ${ }^{87}$ and coincided with the decisions reached by three other courts in the same situation. 88

The disadvantageous effects of the unsatisfactory grounds for decision put forward in Mertz v. Mertz were felt in the subsequent case of Coster v. Coster $^{89}$ the facts of which occurred after the New York legislature had deliberately abolished the common law incapacity of spouses to sue one another.90 The parties were residents of New York. The injury occurred in Massachusetts where the common law incapacity prevailed. The parties married after the plaintiff had brought her suit in New York. Had the opinion in the Mertz case emphasized the application of the New York rule to New York residents instead of public policy and the scope of the remedy, it might have provided a suggestive analogy. Had the Mertz case never existed, the court might conceivably have approached the Coster case as a new problem posed by the recent New York statute. Unfortunately, the Mertz opinion hung over Coster v. Coster like a bank of fog. The plaintiff's legitimate argument that the law of her domicile permitted her to sue91 became hopelessly con-

86 Note, 6 Brooktrw L. Rev. 100 (1936); Note, 5 FordHAM L. REv. 496 (1936); Note' 50 Harv. L. Rev. 351 (1936); Note, 1 Mo. L. Rev. 348 (1936); Note, 14 N.Y.U.L.Q. REV. 93 (1936); Note, 11 St. Joh.'s L. Rev. 122 (1936); Note, 10 U. CrNC. L. REv. 473 (1936); Note, 3 U. PITr. L. REv. 128 (1936). These writers all deplored the decision in the Mertz case as a provincial-minded retreat from the Loucks opinion, needlessly sacrificing cherished choice-of-law objectives such as uniformity and enforcernent of vested rights.

87 A very perceptive comment defending the Mertz decision on functional grounds appeared in 31 JLL. L. Rev. 792 (1937). Note, 36 Colum. L. REv. 1158 (1936) recognized that the court had some justification for applying the disability of New York law to New York resident spouses but deprecated the result.

88 Poling v. Poling, 116 W.Va. 187, 179 S.E. 604 (1935) (defendant wife resident in Washington, D.C.; plaintiff husband resident of forum), disapproved in Note, 4 FordHay $L$. REv. 475 (1935); Kircher v. Kircher, 288 Mich. 669, 286 N.W. 120 (1939), disapproved in Note, 38 Mich. L. Rev. 715 (1940); Kyle v. Kyle, 210 Minn. 204, 297 N.W. 744 (1941), disapproved in Note, 25 MiNN. L. REv. 944 (1941).

39 289 N.Y. 438, 46 N.E.2d 509 (1943).

90 N.Y. DOM. REL. LAw $\S 57$ (1937). At the same time the legislature enacted N.Y. INs. LAW $\S 109$ (3-a) relieving insurers of liability for injuries to the person or property of the spouse of the insured unless specifically covered by the policy. But this latter section had no application to Coster v. Coster since the plaintiff was not the wife of the insured at the time the injury occurred. For a discussion of the coverage problem raised by the insurance section and the cases decided in New York and elsewhere see Risjord, Conflict of Laws Applicable to Standard Automobile Liability Policy, 1957 WIS. L. REv. 587, 594-98; Comment, 15 WASH. \& LEE L. REV. 266 (1958).

91 Plaintiff's counsel argued that "the effect of subsequent marriage depends upon the law of New York, the matrimonial domicile and forum" 289 N.Y. at 439, and this argument was restated in the opinion. 14 . at 441,46 N.E.2d at 511. 
fused with the swollen generalities of the Mertz opinion about capacity being governed by the law of the forum and the definition of public policy. The judges resolved to repudiate those swollen generalities and since they supported the plaintiff's case, that case went down the drain with them. Judge Cardozo's restrictive statement of the conditions under which foreign law would not be recognized was approved and applied. Plaintiff's capacity to litigate with her husband was classified as "a substantive right, a part of her cause of action and not a mere matter of remedy."92 Having set at rest these atstract definitional questions, the court was content to follow Buckeye $v$. Buckeye which it cited as representative of the generally accepted doctrine. 93

When contrasted with the Buckeye v. Buckeye type of case, Mertz v. Mertz and its group of congruent precedents poses an interesting problem in the analysis of judicial thinking. In the Buckeye type of case the judges were apparently so distracted and bemused by the issues inherent in orthodox choice-of-law principles that they arrived at a decision flatly inconsistent with the policy of their local legislation. Yet the judges who decided the Mertz $v$. Mertz group of cases seem to have coolly manipulated the escape devices of the choice-of-law system to reach a result in perfect harmony with the policy of the local law. Why did the intuition which guided the judges to a functional conclusion in one situation completely fail to cperate in the other? No doubt judicial intuition was operating (or trying to operate) in both situations, but in the intricate mazes of choice-of-law theory intuition alone is not enough. The explanation for the difference in results is to be found in the attractiveness to judges of the solution provided by the public policy escape device in cases where the facts have some connection with the forum and the domestic rule of the forum would deny recovery. Mertz $v$. Mertz was a case of this general type: the place of injury would have given the wife a cause of action but the law of the forum-domicile set up an ironclad defense. For handling cases of this nature judges (and lawyers) long ago worked out an effortless albeit somewhat fictional short-cut. Instead of grappling with classification and renvoi puzzles or struggling to evolve a new choice-of-law principle, they have simply waved the wand of "public policy" and dismissed the plaintiff's action.94

$92 \mathrm{Id}$. at 442, 46 N.E.2d at 511. Chief Judge Lehman who had written the opinion in the Mertz case did not participate in the decision of Coster v. Coster.

93 In contrast with the chorus of adverse criticism provoked by the Mertz case only one law review comment on Coster y. Coster was forthcoming. As this writer viewed the case, everything turned upon whether the Massachusetts law extinguished the wife's cause of action or merely barred the remedy. Having concluded that the "weight of authority" supported the former view he pronounced the decision "correct." 12 ForDHAM L. REv. 182 (1943).

94 See Paulsen \& Sovern, supra note 63, at 987: "First, public policy can serve as a substitute for thinking." The negative compromise result may also be associated, as in the Mertz opinion, with the remedial classification-the rule of the forum is one which denies a remedy. For detailed discussion of a famous example see Currie \& Lieberman, Purchase-Money Mortgages and State Lines: A Study in Conflict-of-Laws Method, 1960 DUKE L.J. 1, 3-8, $43-46,49-54$. 
Though the effect of such a judgment in other states has never been clarified, the judges in such cases have apparently assumed that they were not adjudicating the controversy on its merits but merely "closing the doors of the court" leaving the plaintiff free to seek a remedy elsewhere.95 Under these conditions the public policy doctrine has been used to effect a kind of fictional compromise; 96 the negative law of the forum, which has some contact with the facts is invoked but in theory is only applied so far as to withhold the aid of the court.

But this negative compromise technique of falling back upon the law of the forum without actually enforcing it to the hilt could not have been used in the Buckeye case or its counterparts where the law of the forum would have given the plaintiff a cause of action. There was no analogous way of rendering a half-hearted judgment for the plaintiff; she either recovered or else she did not. 97 Within the orthodox choice-of-law framework the judges who decided the Buckeye line of cases had to either follow the well-established place of injury principle or utilize one of the alternative devices we bave already considered.

\section{Dissatisfaction with the "Buckeye" Case}

Let us return now to Wisconsin to trace the subsequent history of the Buckeye doctrine in its home state. Sometimes the overruling of an older precedent is heralded by a group of cases in which it is criticized or narrowly distinguished. Such was not the fate of Buckeje v. Buckeye. Yet several of the

95 This statement of what the judges think they are doing is supported by Paulsen \& Sovern, supra note 63 , at 1010 . See also the RESTATEMENT, JUDGMENTS $\$ 49$, comment $a$ (1942). As Paulsen \& Sovern point out, however, a successful suit in another state would frequently be seen to stultify the policy of the forum if that policy were clearly stated. If the purpose of the New York rule involved in the Mertz case was to prevent New York couples from taking certain types of fanily disputes to court, or to preserve the general image of the harmonious home, litigation by a New York couple in another state would be within the scope of the prohibition. Moreover, to say that the New York rule "denies a remedy" has the unfortumate effect of actually encouraging courts in other states to pay no attention to it. See Currie \& Lieberman, supra note 94, at 53-54.

96 "Fictional" because the unfortunate plaintiff whose action has been dismissed may be unable to obtain jurisdiction over the defendant in another state. Even if he can, the statute of limitations in the second state may have run while be was exhausting the available time with his first fruitless suit.

97 In Coster y. Coster, since the parties were domiciled in New York, the court might have applied the New York rule allowing recovery on the ground that the Massachusetts rule barring recovery was contrary to New York "public policy." The judges would thus have avoided the necessity of reconciling their conclusion with cumbersome choice-of-law principles. But they could not have adopted the neutral or "compromise" attitude of merely closing the door of the court; they would be quite obviously rendering a judgment for the plaintiff. Hence resort to the phrase "public policy" under these circumstances does not appeal to the judges in the way the negative compromise does and it is rarely found in the cases. In two of the cases patterned after Buckeye v. Buckeye, counsel tried to induce the court to reject the rule of the state of injury as against the public policy of the forum-domicile but without success. See How 4 rd v. Howard, 200 N.C. 574, 158 S.E. 101 (1931); Bohen k v. Niedzwiecki, 142 Conn. 278, 113 A.2d 509 (1955). 
cases decided during the last years of its regime indicate a warm receptiveness on the part of the judges towards ingenious, arguments which, in effect, permitted the application of Wisconsin law to suits between Wisconsin spouses injured in other states. Counsel too seem to have understood that such an attitude existed for they were not hesitant in putting forward such arguments at every opportunity. 98

Nelson v. American Employers' Ins. Co.,99 decided in 1951, involved a Wisconsin wife who had been injured in New Mexico. In 1897 a New Mexico statute 100 had been enacted providing that "a married woman shall sue and be sued as if she were unmarried." During the ensuing fifty-five years there had been no New Mexico case holding that this statute had changed the common law rule prohibiting suits between spouses for personal torts. Nevertheless the Wisconsin court, noting the similarity of the New Mexico and Wisconsin statutes ${ }^{101}$ and actually citing its own decision in Wait v. Pierce, ${ }^{105}$ took it upon itself to construe this statute as effecting a change in the common law of New Mexico. In the Buckeye case the court had ignored the Wisconsin statute, the Wait case and the policy considerations there discussed, preferring to hand the problem over to the law of the state of injury; now, somewhat ironically, we find the Wisconsin court turning to these very factors for aid in bending the law of the state of injury to a more favorable posture.

98 See, in addition to the cases discussed in the text, Scholle v. Home Mut. Cas. Co., 273 Wis. 387,78 N.W.2d 902 (1956), in which the trial judge found, on very flimsy grounds, that the law of the place of injury would permit the plaintiff to recover, and Garlin v. Garlin, 260 Wis. 187, 50 N.W.2d 373 (1951), where, for reasons not apparent at all, the trial iudge did not follow Buckeye.

99258 Wis. 252, 45 N.W.2d 681 (1951).

100 N.M. STATS. ANN. \$21-6-6 (1953).

${ }^{101}$ At the date of the Nelson case, the Wisconsin courts were empowered by statute to take judicial notice of the laws of other states. Wis. Laws $1947 \mathrm{ch}$. 363. The court's venturesome prediction that New Mexico would follow Wisconsin's lead was proven wrong in Romero v. Romero, 58 N.M. 201, 269 P.2d 748 (1954).

In Hansen v. Hansen, 274 Wis. 262, 80 N.W.2d 230 (1950, the court attempted to justify the course taken in the Nelson case on the authority of Howe v. Ballard, 113 Wis. 375, 89 N.W. 136 (1902). When the Howe case was decided Wisconsin courts did not take judicial notice of the laws of other states. If the statutes or cases of another state were not proved at the trial, the supreme court, on appeal, would presume the law of the other state to be the same as that of Wisconsin, including Wisconsin statutory law. See Walsh v. Dart, 12 Wis. 635 (1860); Slaughter v. Bernards, 88 Wis. 111, 59 N.W. 576 (1894), and cases cited in Baldwin \& Dodge, Judicial Notice and the Model Code of Evidence, 1945 WIS. L. REv. 192, $196 \mathrm{n} .26$. In the Howe case a Kentucky statute was put in evidence at the trial but the cases construing it were not. On appeal the court quoted the Kentucky statute but declined to consider the Kentucky cases and stated: "in the absence of proof to the contrary, where proof of a foreign law is material to a cause of action or defence, and none is produced, we must presume that our own law on the same subject, and such foreign law, similarly worded, have the same meaning." 113 Wis. at $379,89 \mathrm{~N}$.W. at 137 . The need for the presumption employed in the Howe case was completely eliminated by the judicial notice statute of 1947. Acting under that statute in the Nelson case the court ought to have made a candid appraisal of the New Mexico law without resort to the Wisconsin law by way of presumption or otherwise.

102191 Wis. 202, 209 N.W. 475 (1926). 
In Jaeger 1. Jueger 10 the plaintiff wife was injured in Arizona whose statute of $1901^{104}$ concerning married women's suits had never been held by the Arizona courts to have altered the common law rule by authorizing personal injury actions between spouses.105 Again the Wisconsin court allowed rccovery by finding that the Arizona law was the same as that of Wisconsin. But this time two judges dissented on the ground that the Arizona legislation was quite different in form from the Wisconsin act. They added that the absence of any Arizona precedent favorable to the wife "is not conclusive but is persuasive that in Arizona it is considered that such an action will not lie,-unless one can believe that in Arizona wives are more submissive or attorneys less enterprising than they are in Wisconsin."106 Of course, this observation applied with equal force to the Nelson case.

Dissatisfaction with the effects of Buckeye v. Buckeye was perhaps most clearly revealed by the opinion in Bodenhagen v. Farmers Mut. Ins. Co., 107 handed down only five months before the older case was overruled. In the Bodenhagen case the husband and wife were residents of Wisconsin and the

103262 Wis. 14, 53 N.W.2d 740 (1952).

10e Ariz. Rev. Stat. $\$ 1302$ (1901). The Wisconsin court referred to Ariz. Cone AnN. \$21-516 (1939).

105 Arizona cases had held that damages for personal injury recovered by a married person were community property and that where a third party caused injuries to one spouse which were due in part to the contributory neligence of the other spouse, the injured spouse could recover nothing from the third party because otherwize the negligent spouse woukd profit from his own wrong. Tinker v. Hobbs, 80 Ariz. 166, 294 P.2d 659 (1956). Citing no authorities, defendants argued that this doctrine of Arizona law would also prevent a wife from suing her husband for personal injuries because the damages, paid from his separate property, would become community property and, in that extraordinary way, he might be said to benefit from his own wrong! This strange riddle of community property law was shrewdly avoided by the Wisconsin court; they held that since the Jaegers were domiciled in Wisconsin, their marital property rights in each others' acquiritions should be determined by Wisconsin law so that Mrs. Jaeger's damages would belong to her alone and Mr. Jaeger would take no share of them. Four years later in Hansed y. Hansen, 247 Wis. 262, 80 N.W.2d 230 (1956), counsel for the plaintiff appears to bave invited the court to treat Jaeger v. Jaeger as having inaugurated, in principle, a departure from Buckeye v. Buckeye, but the invitation was declined. Nevertheless, these exercises in the subtleties of community property law, an exotic casuistry with which the judges presumbly had little familiarity, may have served to underscore the inconvenience as well as the unfairness of the Buckeye rule.

The choice-of-law position taken by the Wisconsin court in Jaeger v. Joeger is soutained by decisions in the community property states. See Hancock, Thee Appromethes to the Choice-of-Law Problem: the Classificatory, the Functional and the Result-Selective, in TwENtieth Century Comparative and Confucts Law: Legal. Easays in Honon of Hestel E. YNTEMA 367-70, 378. I have never found any case in a community property state where the rule that damages recovered from third partice become community property has been beld to prevent suits between the spouses themsetves. In Lorang v. Hays, 69 Idaho 440, 209 P.2d 733 (1949) it was held that Idaho law permitted suits between spouses and thoush the damages recovered by one of them from a stranget would have been community property, those recovered in the present suit would be the separate property of the plaintiff.

106262 Wis. at 21,53 N.W.2d at 744.

$10^{-} 5$ Wis. $2 d$ 306, 92 N.W 2d 759 (1958). 
wife had been injured in Illinois. But certain intervening developments there enabled the Wisconsin court to reappraise the Illinois law of interspousal litigation. In 1952 the Supreme Court of Illinois with two judges dissenting had decided (reversing the appellate court) that, properly construed and understood, the Illinois Married Women's Act of 1874 had actually conferred upon married women the power to sue their husbands for personal torts.108 The statute was given a construction both literal and liberal, Main v. Main was brushed aside, the happy home argument was ridiculed and Illinois adhered to what the court cautiously called, "perhaps the present trend in judicial opinion." 109 However, the Illinois legislature of 1953 promptly altered this

to8 Brandt v. Keller, 413 Ill. 503, 109 N.E.2d 729 (1952), reversing 347 Ill. App. 18, 105 N.E.2d 796 (1952). Referring to the plaintiff's contention that, although the common law disability prevented suit by the husband, the Married Women's Act of 1874 had authorized suit by the wife, the Appellate Court remarked that, "such a swing of the pendulum would certainly crash through the walls of grandfather's clock even though he himself wrote the Act." 347 Ill. App. at 20, 105 N.E.2d at 797.

109413 III. at 510, 109 N.E.2d at 732. As indicated above (see text at note 20 supra) the only states in which, before 1932, one spouse had recovery against the other for automobile negligence were those which had previously allowed such suits for assaults-and Wisconsin. Between 1931 and 1952, four states which had never before permitted interspousal suits for personal torts allowed them for automobile negligence. See Rains v. Rains, 97 Colo. 19, 46 P.2d 740 (1935); Fitzmaurice v. Fitzmaurice, 62 N.D. 191, 242 N.W. 526 (1932); Damm v. Elyria Lodge No. 465, 158 Ohio St. 107, 107 N.E.2d 337 (1952); Scotvold v. Scotvold, 68 S.D. 53, 298 N.W. 266 (1941).

In these cases the judges maintained a dignified silence regarding the omnipresent factor of liability insurance. But in two other cases decided during the same period we find a candid and realistic statement of its relation to the immunity question. While a single insurance contract may be regarded as a purely private transaction in which one legal person undertakes to protect another against judgments for damages, the widespread practice of making such contracts may also be regarded as a desirable social activity, encouraged and regulated by the state, because it tends to secure pecuniary compensation to the injured victims of highway traffic and to distribute the loss among the motoring public. Presented in this context, the marital immunity doctrine sounds a harsh discordant note in at least $t w o$ respects. First, the happy home policy, for what it is worth, becomes completely irrelevant; the husband and wife are not squabbling in public but establishing a claim to compensation. Second, if we visualize the husband as a responsible citizen, buying insurance to protect all persons who may become involved in accidents with him, why should his wife, of all people, be deprived of the benefits of this insurance? These ideas will be found expressed (partially) in Courtney v. Courtney, 184 Okla. 395, 403, 87 P.2d 660, 668 (1938), and in McKinney v. McKinney, 59 Wyo. 204, 236-44, 253, 135 P.2d 940, 951-55, 958 (1943). In the latter case, Justice Blume (concurring) suggested that the court should follow the example set by other courts in dealing with parental immunity to suit by children and hold that the husband would be liable for the wife's injury if he had insurance but not otherwise. Chief Justice Kimball (dissenting) argued that since the uninsured husband would rarely be brought to court anyhow "there is no reason for continuing the disability under modern business and social conditions." One cannot help suspecting that the judges in the first four cases probably had similar thoughts. For discussion of situations where the presence of insurance removes the policy basis of an immunity see Streit, The Carrying of Liability Insurance as Creating Tort Liability, 1952 INs. L.J. 602.

A similar trend of thought regarding the effect of insurance appears in Edwards v. Royal Indemnity Co. 182 La. 171, 161 So. 191 (1935) where the Louisiana court sustained a wife's suit against the husband's insurer for ante-nuptial automobile negligence under the Louisi- 
newly discovered law by enacting that "neither husband nor wife may sue the other for a tort to the person committed during coverture."110

In the Buckeye case, the court had stated emphatically that the ancient common law prohibition (believed to be in force in Ilinois) was not a rule "affecting the remedy" which the Wisconsin court might therefore ignore. But in the Bodenhagen case that court announced that the Illinois statute, strictly construed, "merely destroys any remedy in the courts of llinois on the type of claim involved."111 The opinion leaves one wondering why the old common law disability could not have been circumvented in the same fashion and by what mystical criterion the court could tell that the statute "merely destroyed the remedy" but not the cause of action. However, the court was trying to apply the Wisconsin law by way of the remedial escape device under the embarrassing circumstances of having previously declared that this escape device was not to be so used; in such situations mystifying distinctions inevitably emerge.

The Bodenhagen opinion ran into another and more serious difficulty. When the principle that remedial matters are governed by the law of the forum is used as an excuse for following a local rule in a case where the facts make important contacts with the forum, there is always the dangerous implication that the same local rule would be applied in a case where those contacts did not exist. In this instance, the statement that the Illinois legislation "merely destroys the remedy in the courts of nlinois" strongly suggests that since the Wisconsin remedy remains unaffected, an Illinois wife, injured by her husband in that state, could recover in a Wisconsin court. Such a result would be extremely undesirable.112 Mr. Justice Fairchild, who wrote the opinion, was apparently aware that it might be construed in this way for he added these explanatory remarks: "Particularly where, as here, the married people involved are domiciled in a state where public policy recognizes both the cause of action and the right to sue, there is no reason to suppose that the Ilinois Legislature was concerned with barring liability completely."113

ana direct-action statute on the ground that the hushand's immunity was a personal defense which the insirer (like a surety) could not refy upon.

The impact of widespread liability insurance did not, however, prevent five courts which had not before considered the point, from deciding (during the period 1932-1952) that interspousal suits for automobile negligence had not been authorized in their states. Corren v. Corren, 47 So. $2 d 774$ (Fla. 1950); Sink v. Sink, 172 Kan. 217.239 P.2d 933 (1952); Conley v. Conley, 92 Mont. 425, 15 P.2d 922 (1932); Comstock v. Comstock, 106 Vt. 50, 169 Atl. 903 (1934); Poling v. Poling, 116 W. Va. 187, 179 S.E. 604 (1935). In all these cases except Sink v. Sink, supra, the courts stated that if a change in the law should seem desirable it was the function of the legislature rather than the courts to initiate it.

110 Ir. REv. Stat. ch. 68, $\$ 1$ (1959).

1115 Wis. $2 d$ at 310,92 N.W.2d at 762

112 See text below at note 141 .

1135 Wis. $2 d$ at $310 a, 92 \mathrm{~N}$ W.2d at 762 . For a functional analysis of a similar case by a single judge see Pryor v. Merchants Mut. Cas. Co., 12 Misc. 2d 801, 174 N.Y.S.2d 24 (1958). 
Here we have a clear recognition of the policy of the Illinois act: it "destroys the remedy" in the sense that no one may bring a suit of this nature in the Illinois courts, but certainly the Illinois legislature was not trying to prevent Wisconsin residents from maintaining such suits elsewhere. This also amounts to a fairly broad hint that despite the general language of the opinion, it is meant to say nothing regarding the statute's effect on Illinois residents. But the ancient conflicts cliches about "right" and "remedy" which have farreaching traditional connotations are not so easily blended with a modest functional approach. The dangerous implications of the holding that a statute prohibiting interspousal suits merely barred the remedy continued to trouble the Wisconsin judges, three of whom had not joined in the decision. After a rehearing the opinion was withdrawn and replaced by one based upon another ground. 114

While the Wisconsin judges were developing techniques for evading the Buckeye doctrine, judges in other states were striking at its very roots by adopting the domiciliary principle which had been advocated by the commentators some twenty years earlier. The first blow was struck by Justice Traynor of California, a judge who had already ventured to flout the orthodox choice-of-law system. ${ }^{115} \mathrm{He}$ did not have the opportunity of dealing with a suit between spouses, but in Emery v. Emery116 (decided in 1955) he was confronted with the problem of minor children suing their father for personal injuries sustained in an automobile accident in Idaho. All parties were domiciled Californians. Writing for the Supreme Court of California, Justice Traynor stated that California domestic law would permit such a suit and disposed of the choice-of-law problem in the following oft-quoted passage:

We think that disabilities to sue and immunities from suit because of a family relationship are more properly determined by reference to the law of the state of the family domicile. That state has the primary responsibility for establishing and regulating the incidents of the family relationship and it is the only state in which the parties can, by participation in the legislative processes, effect a change in those incidents. Moreover, it is undesirable that the rights, duties, disabilities, and immunities conferred or imposed by the family relationship should constantly change as members of the family cross state boundaries during temporary absences from their home. ${ }^{117}$

114 See 5 Wis. 2d 310a, 95 N.W.2d 822 (1959). See explanation in Haumschild v. Continental Cas. Co., 7 Wis. 2d 130, 140, 95 N.W.2d 814, 819 (1959).

11s Grant v. McAuliffe, 41 Cal. 2d 859, 264 P.2d 944 (1953), reversing 255 P.2d 819 (Cal. App. 1953). For a comprehensive functional analysis of the problem involved see Currie, Survival of Actions: Adjudication Versus Automation in the Conflict of Laws, 10 STAN. L. REV. 205 (1958).

11645 Cal. 2d 421, 289 P.2d 218 (1955). For an appraisal of the decision in the light of previous cases and illuminating analogies, see Ehrenzweig, Parental Immunity in the Conflict of Laws: Law and Reason Versus the Restatement, 23 U. CrI. L. REv. 474 (1956).

11745 Cal. 2d at 428, 289 P.2d at 223. 
Less than two years later a Pennsylvania Common Pleas Court decided that (under local law) a wife, though barred from suing her husband for personal injuries during his lifetime, acquired a cause of action which she might enforce after his death against his estate.118 To the contention that such was not the law of Florida where the injuries occurred the court, citing Cook, Rabel and Rheinstein."19 replied that "many commentators and text writers, by what appears to us much more persuasive reasoning, have demonstrated that this question should be determined by reference to the law of the domicile." 120 Since the husband and wife had been at all times domiciled in Pennsylvania, the wife's action was allowed to proceed.

These two pioneer cases, the first in which the judges explicitly rejected the law of the state of injury in favor of that of the parties' residence, have one intriguing feature in common: they were both cases in which the domestic rule of the domicile-forum was itself unsettled.121 In these circumstances the judges had to dispose of two interrelated questions: (1) what should be the local law and policy? (2) if the foreign and local laws differed which one ought to prevail? To the judges the first of these questions was of the more familiar type: they were called upon to consider the local statutes, the local precedents, the trend of opinion elsewhere and so to determine the proper rule for their state. In the course of these cogitations they probably tended to assume that "for their state" meant for the people of the state who through the constitutional machinery had selected them and others to administer the laws. Hence these judges may well have felt some resistance to the suggestion that though all parties to the instant case were local residents, the newly-announced iaw

118 Pittman v. Deiter, 10 Pa. D.\&C.2d 360 (1957). The presiding justice of this court was Curtis Bok, now a member of the Supreme Court of Pennsylvamia, author of Bncscone of THE HERRING (1941) and I TOO, NicODEMUS (1946).

1191 Rabel, The Cosflict of Laws: A Comparative Study 322 (1945). The court's citations to Cook and Rheinstein were the same as those in notes 73 \& 74 supra.

$12010 \mathrm{~Pa}$. D.\&C.2d at 361 . The Supreme Court of Pennsylvania reached the same result on similar facts in Johnson v. People's First Nat'l Bank, 394 Pa. 116, 145 A.2d 716(1958), but the discussion of the choice-of-law point is meager and obscure. The decision in the Pittman case was approved in Note, 4 WAYNE L. REV. 79 (1957); Packel, Backward and Forward in Conflicts, 31 TEMP. L.Q. 117 (1958).

121 Regarding the challenging problem of conflict cases in which the local law is not elear, Justice Traynor himself has written: "It [the court] is as concerned in a conflict case as in any other with optimum justice. It is alerted as in no other to alternatives that may reveal shortcomings in its own law, and its enlightenment in such a case is bound to extend to purefy local cases also. ... It may well find that the policy of the other state is not enlightened and indeed so backward as to call for resistance. Should it also find that the local policy has not yet been articulated in statute or precedent, it may proceed to articulate it for the first time, for purely local as well as interstate cases, and thereby create an open conflict with the other policy. Thus the court has a dual responsibility. Within the confines of policy based on precedent, it can revise backward local precedent to harmonize with an enlightened policy of another state. It can also set an enlightered local precedent to conflict with the backward policy of another state." Is This Conflict Really Necessary? 37 TeXas L. Rev. 657, 673 (1959). 
and policy could not apply to them' because, forsooth, the accident had occurred beyond the boundary. Or, to state the point negatively, it was not perhaps so easy for these judges, laboring to produce a sound rule of local law, to treat the result of their best efforts as mere datum to be casually run through the choice-of-law machinery.

Koplik v. C. P. Trucking Corp., 122 decided by the Supreme Court of New Jersey in 1958, presented the same pattern of laws and facts as. Mertz v. Mertz except that the parties did not marry until after the action was begun. Most of the controversy centered on the New Jersey domestic law which was finally held by a four to three majority to prohibit suit under those circumstances. Although the accident occurred in New York, whose law would have permitted such a suit, the court cited and followed Mertz v. Mertz but added that,

it is sensible and logical to have disabilities to sue and immunities from suit arising from the family relationship determined by reference to the law of the state of the family domicile when the suit is brought in that state. Otherwise, the lex loci will be permitted to interfere seriously with a status and a policy which the state of residence is primarily interested in maintaining. 123

Thus, twenty-two years after Mertz 1. Mertz was decided the justification for the decision on the ground that the parties were residents of the forum finally achieved judicial recognition in lucid and functional language.

We have now set the stage for our consideration of Houmschild v. Continental Cas. Co., 124 in which Buckeye v. Buckeje was overruled. The parties were domiciled in Wisconsin; the plaintiff wife was injured in California, which still adhered to the common law disability. In the opinions, as in the last act of an opera, we find repeated many of the same themes which had run through Buckeye r. Buckeye and its related decisions. Counsel for the plaintiff had not asked the court to abandon the place of injury principle. He had assumed that California law would be applied but relied upon the opinion in Emery y. Emery to show that a California court would, in a like case, invoke the Wisconsin domestic law. Hence, by a species of renvoi the Wisconsin statute permitting suit would govern the decision. But the majority shrank from adopting "the much criticized renvoi principle," pointing out that it had been rejected by many leading authorities because "it is likely to result in the court pursuing a course equivalent to a never-ending circle." 125 The remedial classification employed in the Bodenhagen case was also briefly discussed; the court stated that grave doubts had been entertained regarding the correctness of this classification and that a new opinion had been prepared along the lines of the present one. The principal theme of the opinion, however, was the argument which had failed in Buckeye v. Buckeye: that the law of the domicile ought to

12227 N.J. 1, 141 A.2d 34 (1958).

124, Wis. 2d 130, 95 N.W.2d 814 (1959).

123 Id. at 11-12, 141 A.2d at 40 .

I2s Id. at 142,95 N.W.2d at 820 . 
determine whether one spouse was immune to suit by the other. Appropriate reference was made to the criticism of the Buckeye case by Cook, Rabel and Rheinstein, 126 to the Mertz $y$. Mertz line of cases which, in effect, enforced the law of the domicile when it prescribed immunity, and to Emery v. Emery and the Pennsylvania case127 which had applied the law of the domicile when it gave no immunity. The court did not mention the tendency to place a strained construction on the law of the state of injury indicated by some of its own recent decisions; perhaps it was considered unnecessary to do so. The argument reached its climax with the plea (already quoted) for a better choice-oflaw principle which would not discriminate against Wisconsin citizens.

But the majority was not content to overrule Buckeye v. Buckeye; they insisted on going further and overruling a very different case, Forbes v. Forbes, 128 decided in 1938 when Illinois was believed to have retained the common law disability. The problem of that case we have already briefly examined without reference to its particular facts. 129 The parties were domiciled in Ilinois; the injury and the litigation took place in Wisconsin. As we have already suggested, a strong functional argument can be made for the application of the Wisconsin statute because of that state's interest in securing medical and other care for people injured there. Of course the policy of Ilinois to prevent its resident husbands and wives from suing each other is antagonistic, but why should the Wisconsin court yield 130 to the old-fashioned policy of another state which it has itself repudiated? The Wisconsin law was in fact applied in the Forbes case but the rationale of the opinion was couched in quaintly formal choice-of-law language. Though the "status" of the parties as husband and wife was governed by the law of their domicile (it was said), their power to sue one another ought to be classified as one of the "incidents of

126 See notes 119, 73, 74 supra. The court aiso referred to Ford, Interspousal Liability for Automobile Accidents in the Conflict of Laws, 15 U. PrTr. L. REV. 397 (1954) in complimentary terms and quoted his recommendation that the question of immunity between spouses should be determined by the law of the family domicile.

127 Pittman v. Deiter, 10 Pa. D.\&C.2d 360 (1957). Sec text at note 118 supra.

128226 Wis. 477,277 N.W. 112 (1938).

129 See text at note 76 supra.

130 In his article of 1956 cited supra note 116, Professor Ehrenzweig suggested that in view of the general prevalence of automobile liability insurance, "suability of a parent by his minor child, as that between spouses, should realistically be determined by that law under which premiums based on the incidence of such suits is most readily calculable by the parent's or spouse's liability insurer. This test points unambiguously to the insurred's domicile rather than to the fortuitous place of form or accident." More recently, this suggestion has been amplified in Guest Statutes in the Conffict of Laws-Towards a Theory of Enterprise Liability under Foreseeable and Insurable Laws, 69 Y ALE L.J. 595, 598 n.29, 603-04 (1960); Products Liability in the Conflict of Laws, 69 YALE L.J. 794, 801 (1960). Evidence of a disposition on the part of any court or courts to adopt this suggested program consciously or explicitly has so far been difficult to find. Several seemingly formidable objections to it have been advanced by Morris, Enterprise Liability and the Actuarial Process-The Insignifcance of Foresight, 70 Y ALE L J. 554 (1961). 
status"' and therefore governed by the law of the place of injury. The authority for making this particular classification was, of course, our old friend Buckeye v. Buckeye supported by the cases on all fours with it decided in other states. ${ }^{131}$ The problem of Forbes $v$. Forbes subsequently came up in North Carolina, New Hampshire and New York; 132 in each case the court decided for the plaintiff stating that it was following the law of the place of injury (which was also the forum).

Now why should the court deciding the Haumschild case have thought it necessary to overrule the perfectly rational and defensible decision in Forbes v. Forbes? The facts of Forbes $v$. Forbes were diametrically different from those of the Haumschild case; on strict principles of stare decisis anything said about Forbes v. Forbes in the Haumschild case would be purely obiter dictum. But strict principles of stare decisis are, unfortunately, often disregarded in conflicts cases. This is the notorious "package deal" phenomenon in action;133 if the law of the domicile is to govern in the Haumschild case it must govern in all cases because that is the traditional form in which choice-of-law principles are stated. Hence to reach a sound decision in the Haumschild case the court must renounce its equally sound decision in Forbes v. Forbes.

Two of the judges refused (in a concurring opinion) to bow to the verbalistic crudeness of the traditional form of stating choice-of-law principles. They were unwilling to overrule Forbes $v$. Forbes and they defended the effect which it had in extending the protection of the Wisconsin statute to married couples who lived there temporarily although domiciled in other states. They proposed to decide for the plaintiff in the Haumschild case without laying down any new choice-of-law principle by distinguishing the Buckeye and other cases on the ground that the California law was exceptional in treating interspousal immunity as a question of status governed by the law of the domicile.

131 Dawson v. Dawson, 224 Ala. 13, 138 So. 414 (1931); Howard v. Howard, 200 N.C. 574, 158 S.E. 101 (1931); Gray v. Gray, 87 N.H. 82, 174 Atl. 508 (1934).

132 Lumberman's Mut. Cas. Co. v. Blake, 94 N.H. 141, 47 A.2d 874 (1946); Bradford v, Utica Mut. Ins. Co., 179 Misc. 919, 39 N.Y.S.2d 810 (1943); Bogen v. Bogen, 219 N.C. 51 , 12 S.E.2d 649 (1941). The Bogen case, a four-to-three decision, illustrates how a court which fails to address itself to the basic policies of the domestic laws can become involved in distracting trivialities. Of the majority, two judges simply relied upon the generai choice-of-law principle for torts adding the strange suggestion that to determine the immunity question according to the law of the parties' common domicile might be a violation of the privilegesand-inmunities clause of article IV of the federal constitution. The two remaining majority judges took their stand upon the unqualified generality of the language of the local statute authorizing married women to sue their husbands and St. Paul's admonition to treat strangers kindly (Hebrews 13:2). The dissenting opinion (in which two other judges concurred)argued for dismissal because(1)if the wife obtained a judgment she could not enforce it at the domicile, (2) the parties were trying to "evade the limitations of the law of their State," and (3) "the plaintiff possessing no legal existence as against the defendant, [under the domiciliary law] the Court has no jurisdiction." The initial comments upon the case exhibit understandable confusion. See 19 N.C.L. REV. 367 (1941); 29 GEO. L.J. 1069 (1941).

133 See text at note 75 supra. The "package deal" aspect of the Haumschild case is explained and discussed with exemplary clarity in Note, 73 HARV. L. REv. 785 (1960). 
The tort las of California is no more concerned uith immunity than is Misionsin's. Thus it makes no difference under the facts of this case whether we look directly to the law of $W$ isconsin to determine that immunity is not available as a defence or look to the lau of Wisconsin only because California, having no general tort principle as to immunity, classifies immunity as a matter of status. 1 -

Perhaps this passage requires some further explanation but, as I read it, the judges seem to be saying that since the reference is to the California law of torts and the California rule of immunity would be treated there as a rule of status. irrelevant to the present case. that rule is really out of the picture, so to speak. The Misconsin statute should be followed either because it is the only rule left in the picture or because the Wisconsin court wishes to decide as a California court would decidc. This comes very close to a forthright functional argument that since California has clearly renounced all interest in the application of its immunity rule in this casel 35 the Wisconsin court ought to apply its oun.

In the same year as the Haumschild case the Supreme Court of New Hampshire, which had adopted the Buckeye doctrine in a series of earlier decisions, 136 arrived at a conclusion similar to that of the Haumschild case by a different train of reasoning. In .Morin v. Letourneau ${ }^{137}$ the parties were domiciled in New Hampshire where spouses could sue each other; the injury occurred in Massachusetts where they could not. As in the Buckeye and Coster cases, the parties did not actually marry until after the injury and filing of the action. The court seized upon this fact to distinguish its earlier decisions and, in effect, adopted a remedial classification. It was pointed out that while the Massachusetts domestic case, Luboritz y. Taines, 138 had undoubtedly held that spouses could not sue each other for ante-nuptial personal torts, the opinion did not state explicitly that such causes of action were extinguished by marriage. "We conclude," said the court, "that the Lubowitz case does not stand for the proposition that marriage operated to deprive the plaintiff of her cause of action, but establishes merely that she may not enforce it against her husband in Massachusetts."139 The court referred to the Haum-

1347 Wis. $2 d$ at 143,95 N.W.2d at 821.

135 In determining the scope of a foreign rule of law the court of the forum ought to give careful attention to relevant decisions of the courts of the state whose law is under consid. eration. An examination of those decisions may reveal that the foreign court has limited the ambit of application of its law so that it does not come into conflict with the law of the forum. See Freund, Chief Justice Stone and the Conflict of Lax's, 59 HARv. L. REv. 1210, 1217-19, 1223-24 (1946); HAxcock, ToRTS IN CoNflict OF LAws 178-80 (1942).

136 Boisvert v. Boisvert, 94 N.H. 357, 53 A.2d 515 (1947); Miltimore v. Milford Motor Co., 89 N.H. 272, 197 Atl. 330 (1938); Gray v. Gray, 87 N.H. 82, 174 Atl. 508 (1934).

137102 N.H. 309, 156 A.2d 131 (1959).

138293 Mass. 39, 198 N.E. 320 (1935).

139102 ‥H. at 313,156 A.2d at 133. 
schild case, to Emery v. Emery and to other recent developments in the conflict of laws supporting the application of the law of the parties' domicile but apparently preferred its own rationale for the case in hand. This had one obvious advantage: the "package deal" fallacy of the broad domiciliary principle was avoided so the court did not feel called upon to renounce the use of the New Hampshire rule in the situation where the injuries were suffered there. ${ }^{140}$ On the other hand, the statement that Massachusetts law merely prevented the enforcement in Massachusetts of a wife's premarital cause of action carries the same undesirable connotation as the similar statement made in the ill-fated first opinion of the Bodenhagen case. It could be construed to mean that a Massachusetts woman injured in that state might enforce such a cause of action against her husband in a New Hampshire court. Such is the plight of judges who try to formulate their reasoning in the language of orthodox choice-of-law doctrine; they carefully avoid one conceptual trap only to fall into another.

\section{Some General Observations}

Much emphasis has been placed in the literature of conflict of laws upon two general objectives, presumably important to all states and to all litigants, which are often assumed to constitute the principal justifications for the existing system of choice-of-law principles. It may be appropriate, therefore, to consider briefly how these objectives figure in the story of Buckeye $v$. Buckeye. The most important of them, which frequently passes under the unfortunate description, "fulfilling the reasonable expectations of the parties," requires that the legal solution of any controversy should be derived from the laws of the states with which the facts were significantly connected at the time when they occurred. This idea closely resembles, as may be seen, the policy against retroactive legislation. ${ }^{141}$ For example, suppose that the Wisconsin court had developed the doctrine of the Bodenhagen case to the point of holding that the Wisconsin statute permitting actions between spouses should be applied in a case where the parties were domiciled and the injury occurred in Minnesota which retained the common law disability. Such a decision would be open to very serious criticism. The Wisconsin statute does not embody any policy regarding the orderly process of litigation in Wisconsin courts. And, unless it has some such policy, there can be no good reason for

140 The New Hampshire court had held that a defendant spouse would be liable for injuries incurred by the plaintiff spouse in New Hampshire although they were domiciled in a state where the common law immunity prevailed. Lumbermen's Mut. Cas. Co. v. Blake, 94 N.H. 141, 47 A.2d 874 (1946), cited in the Morin case, 102 N.H. at 312, 156 A.2d at 133.

141 For more general and discursive treatment of this choice-of-law policy see Hancock, Choice-of-law Policies in Multiple Contact Cases, 5 U. Toronto L.J. 133, 135, 137-40 (1943); Rheinstein, The Place of Wrong: A Study in the Method of Case Law, 19 TuL. L. REv. 4, 17-31 (1944); Currie, The Verdict of Quiescent Years: Mr. Hill and the Confict of Law's, 28 U. CHI. L. REv. 258, 289-94 (1961). Despite differences of terminology and emphasis, I believe we are all talking (or trying to talk) about the same general idea. 
extending it to cover transactions occurring in another state, involving people who are not residents of Wisconsin. Of course we cannot say that the defendant husband's conduct was lawful under Minnesota law or that he had a "reasonable expectation" that he could injure his wife with impunity. Nevertheless, in the eyes of thoughtful lawyers it would seem quite unjust to foist upon the defendant, after the event, a liability based exclusively upon the law of the forum. Perhaps it was a feeling that one passage in the first opinion of the Badenhagen case might be interpreted as encouraging a tendency towards such a result which moved the Wisconsin court to withdraw it. Be that as it may, the policy requiring significant contemporaneous contacts has not come into play in any of the reported cases relevant to the subject of this article. In all of those cases the forum was also the state of injury or the domicile of the parties. 142

Quite different from the choice-of-law objective just considered, though frequently confused with it, is the somewhat ambitious goal of achieving complete uniformity in conflicts cases. Even when the facts of a controversy are connected with two different states, it has been thought that choice-of-law principles ought to indicate a single satisfactory course of reasoning for deciding that controversy so that whether suit should be brought in one state or the other the result would be the same. Forum maneuvering by either party ought to be discouraged. Difficulty in realizing this laudable objective is encountered, however, when the laws and policies of the states concerned are in opposition. Recurring to our usual example, suppose the husband and wife were domiciled in New Jersey but the wife was injured in North Carolina. In the Koplik case ${ }^{143}$ the New Jersey court held that its rule forbidding suits between spouses ought to be applied to couples domiciled there although the law of the state of injury was otherwise. Four cases previously decided in other states support this view. ${ }^{4}$ What will happen then, if the New Jersey couple decide to litigate their controversy in North Carolina whose law permits such suits? Considering that the injured wife might become a burden to the state or its residents, a strong policy argument can be made from the North Carolina point of view for resort to its law. The North Carolina case of Bogen v. Bogen14s holds that the wife may recover, notwithstanding the contrary rule of the domicile. This result is supported by three similar cases decided in other states. ${ }^{146} \mathrm{So}$, in this

142 There is one exceptional case, Bourestom v. Bourestom, 231 Wis. 666, 285 N.W. 126 (1939) in which the parties were domiciled in Minnesola where surts between spowses were not permitted, the injury occurred in Otlahoma where such suits were permitted (see Courtney v. Courtney, 184 Okla. 395, 87 P.2d 660 (1938) and the action was brought in Wieconsin. The plaintiff was allowed to recover. The Bourestom case was overuiled in the Hawnsefild case to satisfy the "package deal" aspects of the domiciliary choico-afthw principle.

143 Koplik v. C. P. Trucking Corp., 27 NJ. 1, 141 A.2d 34 (1958).

14 See authorities cited notes $79 \& 88$ supra.

145219 N.C. 51, 12 S.E.2d 649 (1941).

146 See authorities cited notes 128 \& 132 supra. 
combination of laws and facts, the pressures of domestic policies have proven too strong for the Utopian pursuit of uniformity.

What degree of uniformity may be expected in a Haumschild type of case where the parties are residents of Wisconsin but the wife is injured in Illinois? If she brings her suit in Wisconsin she will certainly recover, but suppose that Illinois is a more convenient forum because important witnesses are available there. Though the Illinois statute of 1953 conceivably embodies some policy concerning couples resident in the state, it is difficult to believe that the lawmakers intended that it should determine the rights of all married couples who chanced to injure one another on Illinois soil. So far as the factual contacts are concerned the case is one of the "false problem" variety. But this does not mean that the injured wife should be allowed to maintain her suit in an Illinois court. Probably the strongest argument which can be advanced in favor of enacting such a statute is that these wife versus husband lawsuits are not genuine adversary proceedings at all but juristic caricatures in which the so-called defendant, because he stands to gain by losing, cooperates with his adversary instead of his insurer who is supposed to be trying to defend him.147 If this be the reason for the statute, the Illinois courts should be closed to all such lawsuits including those between residents of other states. Here again we find the normal application of domestic laws incompatible with the visionary ideal of complete uniformity.

One final question remains. If the Buckeye case was overruled because it denied to Wisconsin citizens the beneficial effects of the Wisconsin law, why did it survive for more than a quarter of a century? Why during that time did the courts of five other states duplicate its result? Since much that has been said in the foregoing pages points toward the answer, it can be stated briefly. The seemingly respectable career of Buckeye v. Buckeye lasted so long because the intrinsic irrationality of the decision was camouflaged by the oversimplified and cumbersome terminology which judges and lawyers continue to employ in arguing and adjudicating conflicts cases. The so-called choice-of-law principles do not explicitly recognize the relevance of the policies of domestic laws; they effectively impede the consideration of such policies by requiring the judge to classify the domestic rules in pairs under some abstract label such as "capacity" or "immunity" although each of the paired rules may embody a different policy. If, nevertheless, the judge still retains a sufficient sense of the policy of his local law to object to the result apparently compelled by the choice-of-law principles, he may be able to avoid that result by way of the public policy doctrine, the remedial classification or some other escape device. However, because the traditional concepts raise these essentially misleading issues of classification, they can so divert the judicial mind that the policy of local law is entirely ignored in the ultimate decision. This is what seems to

147 See Cook, What Law Governs Intrafamily Immunity? 27 INS. CoUnsel J. 143 (1960); Smith v. Smith, 205 Ore. 286, 310, 287 P.2d 572, 583 (1956). 
bave happened in the first four cases of the Buckege pattern. In ench of thece cases different issues were raised and debated, but all of them were abutract issues derived from the traditional system, totally unrelated to anything 20 specific as the policy of the local married women's statute. It is not surprising that in each case the policy of that statute was disregarded. No doubt there was a certain element of unfortumate coincidence in these decisions; there was sufficient fiexibility in the orthodox system to permit any one of them to go the other way. But, once decided, four identical conflicts cases raching the same conclusion made an impressive weight of authority which, for many years, few judges cared to dispute. 148

Although in the Mertz v. Mertz line of cases where the forum-domicile prohibited interspousal suits, the courts in denying recovery appeared to be effectuating local policy. It would be wrong to infer that this represented a different judicial approach to conflicts problems or a tendency to discard the conceptual mechanisms of the orthodox system. The implementation of local policy in this group of cases was greatly facilitated by the availability of a wellestablished escape device, the public policy negative compromise. This is also the most satisfying of the escape devices because it appears to pay due respect to the local law without conclusively enforcing it against the plaintiff and to render unnecessary a more thoroughgoing analysis of the choice-of-law problem. Likewise in cases of the Forbes $\nabla$. Forbes pattern, where the state of injury (also the forum) permitted sponses to sue each other, the courts reached a functionally sound result in applying their local law. Yet here again judicial intuition was mightily assisted by conventional choice-of-law doctrine; these cases were all decided by courts which had previously adopted the Buckeye principle that the law of the state of injury should govern marital immunity. By a happy coincidence the "package deal" aspect of that far-reaching principle supported a conclusion in harmony with the compensatory policy of the local law. For aught we know the "package deal" may have swayed some judges more.

Though the cases decided since $1955^{149}$ may be said to evince a heightened judicial sense of the importance of domestic policies, it would be a mistake to conctude that the benumbing grip of the traditional concepts which so often deadens that sense of policy had been broken. When the Supreme Court of Wisconsin decided that it was unreasonable for injured wives to be prevented from collecting insurance because they were hurt outside the state, it turned first to the traditional remedial classification as a means to avoid the Buckeje

145 Perhaps I should acknosiledge that I too was unduly impressed by this stricins unanimity of judicial opinion when I wrote: -Thus there may now be nid to criet an established jurisprudence upon the point, which, though not immune to criticiem, probably ought to be followed for the sake of consistency and prodictability:" Tonts Ix Trie Co:Fuict of Laws 236 (1942).

149 See notes 107, 117, 118, 127, 124, 137 supra. 
principle. 150 More recently, in a similar quandry, the Supreme Court of New Hampshire has shown a strong preference for this well-worn loophole.151 No doubt the Wisconsin court came closer to a clear view of the policy coverage problem when, in the Haumschild case, it discarded the Buckeye doctrine in favor of the domiciliary principle.152 Yet even at the height of its progressive emancipation we find this court entangled in the snare of the "package deal," overruling Forbes $v$. Forbes without any adequate analysis of the policy factors involved in that very different case. Two of the justices properly refused to participate in this strange maneuver. They undertook in a concurring opinion, to formulate realistically the basic elements of the problem: the policies of the Wisconsin and California rules as applied to the instant case, including such enlightenment as might be derived from the California conflicts precedent Emery v. Emery. 153 Since the traditional terminology impeded rather than aided this attempt, the result was not as lucid as might be desired. On the same point, however, the majority retreated far into the cavern of orthodox dogma, refusing to take the least notice of California conflicts doctrine, and unblushingly rehearsing the hoary anti-renvoi sophism of the "neverending circle."

"The power of words is the most conservative force in our lives."154 In legal thinking its influence is particularly oppressive. 155 Certainly the modern student of the conflict of laws should always be alert to the effects of the policies of domestic laws, especially those of the forum; an analysis in terms of such policies would sustain the results reached in most of the cases we have discussed. But our review of the history of Buckeye v. Buckeye would also suggest that he should have a sophisticated acquaintance with the typical verbalistic mechanisms of our venerable choice-of-law principles and their escape devices. He ought to know how and why the conundrums of classification divert the judge's mind from delicate questions of policy and almost convince him that such questions do not exist. He ought to realize the curious conceptual force of the "package deal" aspect of standard-form choice-of-law principles. He ought to understand why judges prefer the negative compro-

150 Bodenhagen v. Farmers Mut. Ins. Co., 5 Wis. 2d 306, 92 N.W.2d 759 (1958).

151 Morin v. Letourneau, 102 N.H. 309, 156 A.2d 131 (1959).

152 The commentators' reactions to the Haumschild case were generally favorable; see 73 HARv. L. REv. 785 (1960); 8 KAN. L. REv. 464 (1960); 45 Iowa L. REv. 175 (1959); Cook, supra note 147. The note in 43 MARQ. L. REv. 127 (1959) adopted a neutral and somewhat dissatisfied tone.

15345 Cal. 2d 421, 289 P.2d 218 (1955).

154 Ogden \& Richards, The Meaning of Meaning 25 (1925), quoted in Green, Judoe AND JURY 43 (1930).

15s See Hancock, Fallacy of the Transplanted Category, 37 CAN. BAR REv. 535, 548-51, 569-71, 572-75 (1959). 
mise to other escape devices 156 in spite of the well-intentioned efforts of thoughtful scholars to exorcise it.157 He should be aware of the subtle but sinister implications of the remedial classification. And, apparently, he must still take account of the possibility that judges can be deterred from the seemingly sensible course of considering what the courts of the other state would do by the celebrated gambits of "ceaseless oscillation" and "cabinet of mirrors."

In the light of these observations regarding conceptual conservatism it may be suggested that our last question should be rephrased to ask, not why did the Buckeye case survive so long, but why did it ever succumb? The chain of events which in combination eventually produced that consequence have already been examined in some detail. Opinions may very well differ, of course, as to their relative force and importance; in this respect the fall of Buckeye v. Buckeye must always remain something of an enigma. Yet for what it may be worth the opinion is ventured here that the critical event, the turning-point of the entire sequence, occurred when the California judges were called upon to determine the common law of their own state in a case which had foreign contacts. 158 Having exercised their normal lawmaking powers in formulating the domestic rule, they were unwilling to abdicate them in favor of mechanistic and irrational choice-of-law dogma. Justice Traynor, who wrote the opinion, remarked upon a subsequent occasion in speaking of Buckeye v. Buckeye: "As it was repeating itself in Connecticut in 1955, we closed the book on it in California."159

156 Whether it operates under the barmer of the public policy doctrine or that of the remedial classification. See notes 94 \& 95 empra.

157 For example, Beach, Uniform Interstate Enforcement of Vested Rights, 27 YalE L.J. 656 (1918); Goodrich, Public Policy in the Lan of Conflicts, 36 K. VA. L.Q. 156 (1930); 3 Benie, Confuct of Lahs 1651 (1935).

15i Emery v. Emery, 45 Cal. 2d 421, 289 P.2d 218 (1955).

159 Quoted, by permission, from a copy of the original manuscript of $L$ This Canglict Really Necesoary?, 37 Texus L. Rev. 657 (1959). 